\title{
Metrics for assessing the downstream effects of dams
}

\author{
John C. Schmidt ${ }^{1}$ and Peter R. Wilcock ${ }^{2}$ \\ Received 10 April 2006; revised 17 October 2007; accepted 19 November 2007; published 5 April 2008.
}

[1] We evaluate three metrics representing the drivers of channel change downstream from dams. A balance between changes in sediment supply and transport capacity identifies conditions of sediment deficit or surplus. A Shields number represents the competence of postdam flows and the potential for incision under conditions of sediment deficit. A ratio of postdam to predam flood discharge provides a metric for the scale and rate of channel change, especially width. The metrics are calculated for more than $4000 \mathrm{~km}$ of some of the major rivers in the western United States. More than $60 \%$ of these rivers are in sediment deficit, and only a few reaches are in sediment surplus. The sediment balance can be used to assess the relative effort involved in reversing undesired conditions of deficit or surplus.

Citation: Schmidt, J. C., and P. R. Wilcock (2008), Metrics for assessing the downstream effects of dams, Water Resour. Res., 44, W04404, doi:10.1029/2006WR005092.

\section{Introduction}

[2] Large dams disrupt flow and sediment delivery downstream, thereby inducing channel change that may extend hundreds of kilometers [Stevens, 1938; Borland and Miller, 1960; Schumm, 1969; Petts, 1979; Williams and Wolman, 1984; Andrews, 1986; Carling, 1988; Brandt, 2000a; Grant et al., 2003]. Some of these channel changes adversely impact cities and towns, agriculture, native riverine ecosystems, and valued landscapes. Environmental management programs now attempt to reverse some undesired channel changes. Because these programs require substantial resources, it is appropriate for the scientific community to provide managers and decision makers with tools to evaluate the factors that cause channel change. Better understanding of the factors that drive channel change might provide a rational basis for distributing scarce national resources to the various programs that attempt river rehabilitation.

[3] In this paper, we propose three metrics that comprise a framework within which the primary drivers of channel change can be assessed. One metric represents the shift in balance between sediment supply and transport capacity and, thus, the tendency for sediment to accumulate or evacuate downstream from dams. Another metric characterizes the postdam stream competence and, hence, potential for channel incision. The third metric is the relative reduction in flood magnitude. Channel incision and flood reduction typically alter the inundation frequency of the predam floodplain, thereby restructuring the disturbance regime and physical template of the riparian ecosystem. Flood reduction is also an important determinant of channel narrowing and

\footnotetext{
${ }^{1}$ Department of Watershed Sciences, Utah State University, Logan, Utah, USA.

${ }^{2}$ Department of Geography and Environmental Engineering, Johns Hopkins University, Baltimore, Maryland, USA.
}

Copyright 2008 by the American Geophysical Union. 0043-1397/08/2006WR005092 the extent to which riparian vegetation invades the postdam channel. We compute these metrics for 61 dam-impacted reaches of five large river systems in the western United States, and we evaluate the utility of these metrics in characterizing channel change by comparison with field measurements. We also discuss the application of these metrics in prioritizing river rehabilitation challenges.

\section{Previous Studies}

[4] Williams and Wolman [1984] summarized channel change in degrading reaches downstream from 21 dams in the western United States and developed empirical relations to predict the duration of incision and the magnitude of changes in channel width. They predicted that more than 100 years will be necessary to achieve maximum incision downstream from some dams. They did not attempt to predict the reach length over which degradation occurs nor where degradation gives way to aggradation further downstream. In addition, Williams and Wolman [1984] did not explicitly characterize the relative change in streamflow and sediment delivery that caused the channel changes they described.

[5] Throughout this paper, we use the term degradation to mean all processes by which sediment is evacuated from a reach. We use the term incision to specifically mean largescale lowering of the bed profile. Thus, incision is only one component of degradation; other components include winnowing of the bed, pool scour without associated lowering of the longitudinal profile, and erosion of bars. We use the term aggradation to mean the general process whereby sediment accumulates in a reach and may, or may not, include changes in bed elevation.

[6] Metrics have been proposed to describe dam-induced disruption of streamflow [Richter et al., 1996; Magilligan et al., 2003; Magilligan and Nislow, 2005; White et al., 2005]. Brandt [2000a] summarized a large number of case studies and identified nine styles of channel change involving either degradation or aggradation. He recognized the applicability of Lane's [1955] conceptualization of the 
interconnected role played by channel slope, discharge, and the rate and caliber of the sediment supply, but he did not evaluate the magnitude of sediment deficit or surplus that arises from different combinations of flow and sediment supply regulation.

[7] Brandt [2000b] and Grant et al. [2003] suggested metrics that consider changes in both water and sediment supply. Brandt [2000b] predicted postdam channel form from regime, bed entrainment, sediment transport, extremal hypothesis, hydraulic geometry, and empirical relations. The accuracy of Brandt's [2000b] method depends on fitted parameters that may not apply generally, and the method's complexity makes it difficult to apply widely. Grant et al. [2003] explicitly evaluated relative changes in flow and sediment delivery. They suggested that channel change is related to changes in the fractional change in duration of sediment-transporting flows and the ratio of sediment supply downstream from the dam to the supply upstream from the dam. They applied these metrics to explain channel change on the Green and Colorado Rivers downstream from Flaming Gorge and Glen Canyon Dams, respectively, and on the Deschutes River.

\section{Metrics}

[8] The primary channel response to dams is either degradation or aggradation, as defined above. These fundamentally different responses are driven by the postdam sediment mass balance that is perturbed into either deficit or surplus. We quantified this perturbation using a simple relation originally suggested by Henderson [1966]. This metric is insufficient, however, to characterize whether or not incision occurs, because incision takes place only if the postdam mass balance is in deficit and postdam floods can entrain the bed. We propose a Shields number as a suitable metric to describe the competence of postdam floods to entrain the bed and thereby to describe the drivers of incision. The third metric, the magnitude of flood reduction, has been previously proposed [Magilligan et al., 2003; Magilligan and Nislow, 2005].

[9] To be useful, it is important that these metrics be reliably estimated from available data. Because data used in regional analysis are often of wide-ranging accuracy and precision, it is desirable that metrics not be highly sensitive to uncertainty in input parameters. Metrics that are computed from estimates of proportional change of predam to postdam conditions are more desirable than metrics based on absolute values, because data describing proportional change in hydrology or sediment supply are typically more accurate than are the absolute values themselves. Reliable information on sediment supply and grain size is often difficult to identify, but the sign and approximate magnitude of these changes can typically be estimated.

\subsection{Sediment Mass Balance}

[10] Change in the sediment mass balance is caused by the relative alteration of the water flux and sediment supply. Prediction of the postdam mass balance is inspired by the widely cited proportionality of Lane [1955]

$$
Q s D \propto Q S
$$

where $Q s$ is the rate of sediment supply and $D$ is its grain size, $Q$ is water discharge, and $S$ is channel slope. A quantitative approximation of this proportionality may be developed by combining equations for momentum, continuity, flow resistance, and transport rate. Henderson [1966, pp. 448-450] developed a simple combination using the Einstein-Brown transport formula, Chezy flow resistance formula, one-dimensional form of the momentum equation for steady uniform flow, and definition of specific discharge. For this formulation, constants representing water and sediment properties and gravitational acceleration cancel and can be disregarded. The Einstein-Brown transport relation is

$$
q s^{*} \propto \tau^{* 3}
$$

where $q s^{*}$ is the dimensionless transport rate

$$
q s^{*} \propto \frac{q s}{D^{3 / 2}}
$$

and $q s$ is the unit sediment transport rate. The Shields number $\tau^{*}$ is

$$
\tau^{*} \propto \frac{\tau}{D}
$$

where $\tau$ is the boundary shear stress. The one-dimensional form of the momentum equation for steady, uniform flow is

$$
\tau \propto R S
$$

The Chezy flow resistance formula is

$$
U \propto \sqrt{R S}
$$

where $U$ is the mean velocity. Specific discharge is

$$
q=U R
$$

where

$$
R \approx h
$$

for wide channels and $h$ is the flow depth. Combining (2) through (8) yields

$$
S \propto \frac{\sqrt{q S} D^{0.75}}{q}
$$

If $q s$ and $D$ represent the rate and caliber of the sediment supply, then $S$ represents the slope needed to transport that supply at a flow rate of $q$. Writing (9) twice, for the same reach under predam and postdam conditions, and taking the ratio gives

$$
\frac{S_{\text {post }}}{S_{\text {pre }}}=\sqrt{\frac{q S_{\text {post }}}{q S_{\text {pre }}}}\left(\frac{q_{\text {pre }}}{q_{\text {post }}}\right)\left(\frac{D_{\text {post }}}{D_{\text {pre }}}\right)^{0.75}
$$




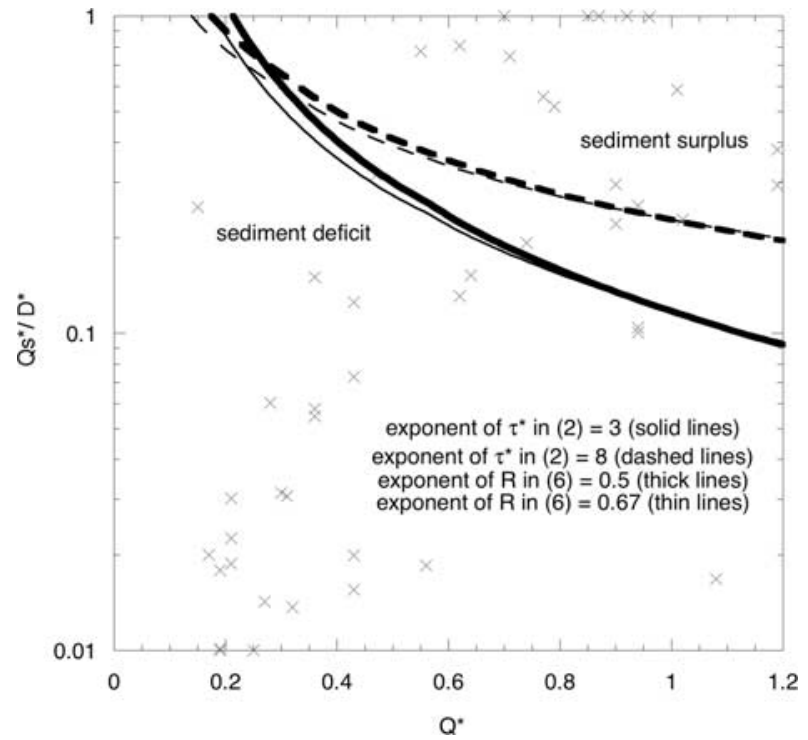

Figure 1. Sensitivity of the threshold between sediment deficit and sediment surplus, i.e., $S^{*}=1$, to parameters used in the derivation of (12). Thin lines indicate $S^{*}=1$, where exponent of $R$ in (6) is 0.67 , and thick lines indicate 0.5 . Solid lines indicate $S^{*}=1$, where the exponent in (2) is 3 , which is appropriate where sand and fine gravel are the dominant sediment supply. Dashed lines indicate an exponent of 8, which is appropriate where coarse gravel is the dominant sediment supply. The crosses show the values of reaches listed in Table 1. The thick solid line is equation (12). The equation of the thin solid line is $S^{*} \propto$ $q s * 0.48 D^{* 0.71} / q^{0.86}$. The equation of the thick dashed line is $S^{*} \propto q s * 0.19 D^{* 1.22} / q$. The equation of the thin dashed line is $S^{*} \propto q S^{* 0.18} D^{* 1.16} / q^{0.86}$.

where the subscripts pre and ${ }_{\text {post }}$ indicate conditions before and after the dam. If channel width is taken as constant, the ratios

$$
S^{*}=\frac{S_{\text {post }}}{S_{\text {pre }}} \quad Q s^{*}=\frac{Q s_{\text {post }}}{Q s_{\text {pre }}} \quad Q^{*}=\frac{Q_{\text {post }}}{Q_{\text {pre }}} \quad D^{*}=\frac{D_{\text {post }}}{D_{\text {pre }}}
$$

can be used in (10), giving

$$
S^{*}=\frac{\left(Q s^{*}\right)^{0.5}\left(D^{*}\right)^{0.75}}{Q^{*}}
$$

Values of $S^{*}$ indicate a potential for degradation or aggradation in response to changes in flow and sediment supply. Values of $S^{*}>1$ indicate that an increase in slope is needed to transport the postdam sediment supply with the specified change in flow. Thus, there is too much supply for the predam slope, and a postdam condition of sediment surplus is predicted. Values of $S^{*}<1$ indicate that that predam slope is larger than needed to transport the postdam sediment supply with the specified change in flow, and a condition of sediment deficit is predicted.

[11] Equation (12) is particularly useful in cases where (1) is indeterminate, which is common in analyzing the effects of dams, because both flow regime and sediment supply are altered. In addition, (12) relies on estimates of the ratio of predam to postdam values, which are easier to estimate than the individual values.

[12] Some imprecision is unavoidable because of approximations made in deriving (12). Even the most precise and accurate calculation of $S^{*}$ is an approximation of the postdam sediment mass balance, which is calculated by

$$
I-E=\Delta S
$$

where $I$ in the influx of sediment, $E$ is the efflux of sediment, and $\Delta S$ is the change in storage of sediment that occurs by channel change.

[13] The choice of resistance relation has a small effect on $S^{*}$. We compared values of $S^{*}$ for $R^{0.5}$, as in (6), and for $R^{0.67}$, as in the Manning relation. $S^{*}$ is not significantly different for either case (Figure 1). The slope of the transport relation, i.e., the exponent on $\tau^{*}$ in (2), has a greater influence on $S^{*}$, especially where $Q^{*}>0.5$ and $Q s^{*} / D^{*}<$ 0.3 . A value of 3 , as given in (2), is representative of rivers whose sediment supply is primarily sand and fine gravel and is a reasonable characterization of the large rivers described in this study. Larger values of the exponent are appropriate where the sediment supply is primarily coarse gravel. A relatively large value of 8 is used for comparison in Figure 1. For the same value of $Q^{*}$, the Einstein-Brown relation, as given in (2), predicts $S^{*}>1$ for smaller values of $Q s^{*} / D^{*}$ and is thus a conservative prediction of postdam sediment deficit.

[14] It is difficult to precisely determine changes in the average grain size of the total sediment supply, because the grain size of each component should be considered in relation to its proportion of the average flux. Examination of (12) reveals that the role of $D^{*}$ is intermediate to that of changes in streamflow and sediment supply. Uncertainty in $D^{*}$ of $\pm 10 \%$ results in an uncertainty in $S^{*}$ of $7.5 \%$. Uncertainty in $D^{*}$ has no effect on characterizing general conditions of sediment deficit $\left(S^{*}<1\right)$ or surplus $\left(S^{*}>1\right)$ if $\sqrt{Q_{s}^{*}} / Q^{*}<0.5$ or $\sqrt{Q_{s}^{*}} / Q^{*}>1.7$ (Figure 2). In those cases where the direction of change in grain size of the supply is known, i.e., fining or coarsening, but the magnitude of the change is unknown, the effect of uncertainty in $D^{*}$ is further reduced. Within the range of $D^{*}$ typical of this study, uncertainty in $D^{*}$ is of concern where $\sqrt{Q_{s}^{*}} / Q^{*}<1.2$ (Figure 2). Where $\sqrt{Q_{s}^{*}} / Q^{*}$ was within this range, we considered the value of $S^{*}$ indeterminate for distinguishing sediment deficit or surplus.

\subsection{Bed Incision Potential}

[15] Sediment deficit is a necessary, but insufficient, determinant of bed incision. The occurrence and extent of incision also depends on whether postdam flows are competent to move streambed material. If flows are not competent, then evacuation of sediment occurs by other processes, but incision cannot take place. In some cases, it is important to make a distinction between the overall grain size of the bed material and the grain size of bed features that act as hydraulic controls. For example, in debris fanaffected rivers where the average bed material may be sand but the bed profile is controlled by boulder rapids, the potential for widespread incision is controlled by the mobility of the bed of the rapids [Schmidt and Rubin, 1995; Grams and Schmidt, 1999]. 


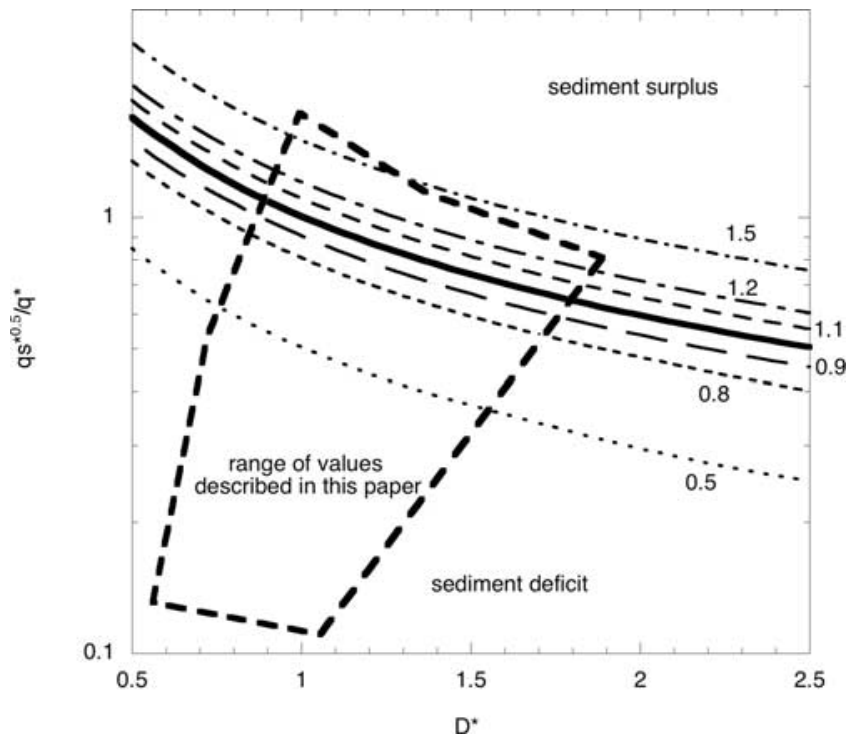

Figure 2. Sensitivity of $S^{*}$ to differences in $D^{*}$. The vertical axis reflects the combined effect of changes in floods and sediment supply, as formulated in (12). Curved lines are different values of $S^{*}$. The range of values for the regulated rivers described in this paper is shown as a dashed box.

[16] The potential for incision at the time of dam closure can be described by a Shields number, $\tau^{*}$

$$
\tau^{*} \propto \frac{h_{\text {post }} S_{\text {pre }}}{D_{B}}
$$

where $h_{\text {post }}$ is the mean depth of postdam floods, $S_{\text {pre }}$ is the slope of the channel at the time of dam completion, and $D_{B}$ is a characteristic bed grain size at the time of dam completion. We compared calculated values of $\tau^{*}$ with field measurements of incision to evaluate the possibility of a threshold value of $\tau^{*}$ above which significant incision had occurred. No attempt was made to predict the magnitude, rate, or duration of incision, because these attributes of incision are determined by the magnitude of sediment deficit, the magnitude and timing of postdam flood releases, and the stratigraphy of the substrate [Grams et al., 2007].

\subsection{Flood Reduction}

[17] Although sediment deficit and surplus determine whether a channel evacuates or accumulates sediment, the rate and type of channel change will also depend on the magnitude of flood flow reduction. The role of flood regime changes in causing channel change independent from changes in $S^{*}$ is anticipated by the broad correlation between flow and width represented in the downstream hydraulic geometry [Leopold and Maddock, 1953]. Inspection of (12) indicates that identical values of $S^{*}$ may be achieved for different combinations of change in flood magnitude and sediment supply, but small values of $Q^{*}$ also anticipate decrease in channel dimensions even where $S^{*}=1$. This suggests the need for a metric that scales the magnitude of flood reduction. We used a ratio of predam to postdam 2-year flood as an index of change in flood magnitude. Reduction in flood magnitude can also promote vegetation establishment in the predam channel, which can accelerate the rate of channel narrowing and reduce the ability of postdam floods to maintain a larger channel [Johnson, 1994, 1998].

\section{Application of the Metrics to Large Rivers of the Western United States}

[18] We summarized conditions of some dam-affected western U.S. rivers where data for flow, sediment supply, and channel change are available: Missouri River, Rio Grande, Colorado River, Trinity River, Snake River, and Deschutes River (Table 1). The Missouri River, Rio Grande, Colorado River, and Snake River drain the Rocky Mountains and adjacent semiarid regions; annual floods typically are caused by spring snowmelt. The Trinity and Deschutes Rivers drain the Coast Range and Cascade Mountains, and their flood regime is caused by winter rain as well as spring snowmelt. The dams and reservoirs that we evaluated were all constructed on rivers except Jackson Lake Dam on the Snake River where the dam raised the stage of an existing lake dammed by Pleistocene moraines. Many parts of these rivers are the focus of rehabilitation programs and have been the subject of extensive channel monitoring and measurement of hydrology and sediment transport. Predam bed material of the Missouri River, Rio Grande, and parts of the Colorado River system was sand. The predam bed of the upper Colorado, Trinity, Snake, and Deschutes Rivers was gravel.

[19] Compilation of data from different rivers and studies necessarily involves integration of information for differing time periods, spatial resolutions, and antecedent conditions. We describe the sources, precision, and accuracy of the data for each reach as auxiliary material ${ }^{1}$. We summarize some of the broader issues associated with our compilation of data below.

\subsection{Definition of Reaches}

[20] The reaches that we defined varied greatly in length (Table 1). The primary criterion used to define each reach was the availability of data with which to describe flow, sediment supply, channel characteristics, and channel change. In some cases, longitudinal changes in these factors or characteristics are well described, and we defined some relatively short reaches; this was not possible elsewhere. Typically, the most upstream reach extended from the dam to the first large tributary. Further downstream, the boundaries of reaches were defined by large tributaries or significant changes in channel geomorphology. In some cases, data were only available for short reaches near gauging stations.

\subsection{Definition of Time Periods}

[21] The lengths of predam and postdam periods were defined by available data. The periods for different data typically do not coincide, and we sought to define periods for flow and sediment supply that were most similar. We used data describing channel characteristics just before dam construction and at the end of the postdam period. In the case of the postdam period, we sought to only use data that isolated the impacts of specific dams.

[22] In the case of the Rio Grande in central New Mexico, we summarized data for similar reaches for two time

\footnotetext{
${ }^{1}$ Auxiliary materials are available in the HTML. doi:10.1029/ 2006WR005092.
} 


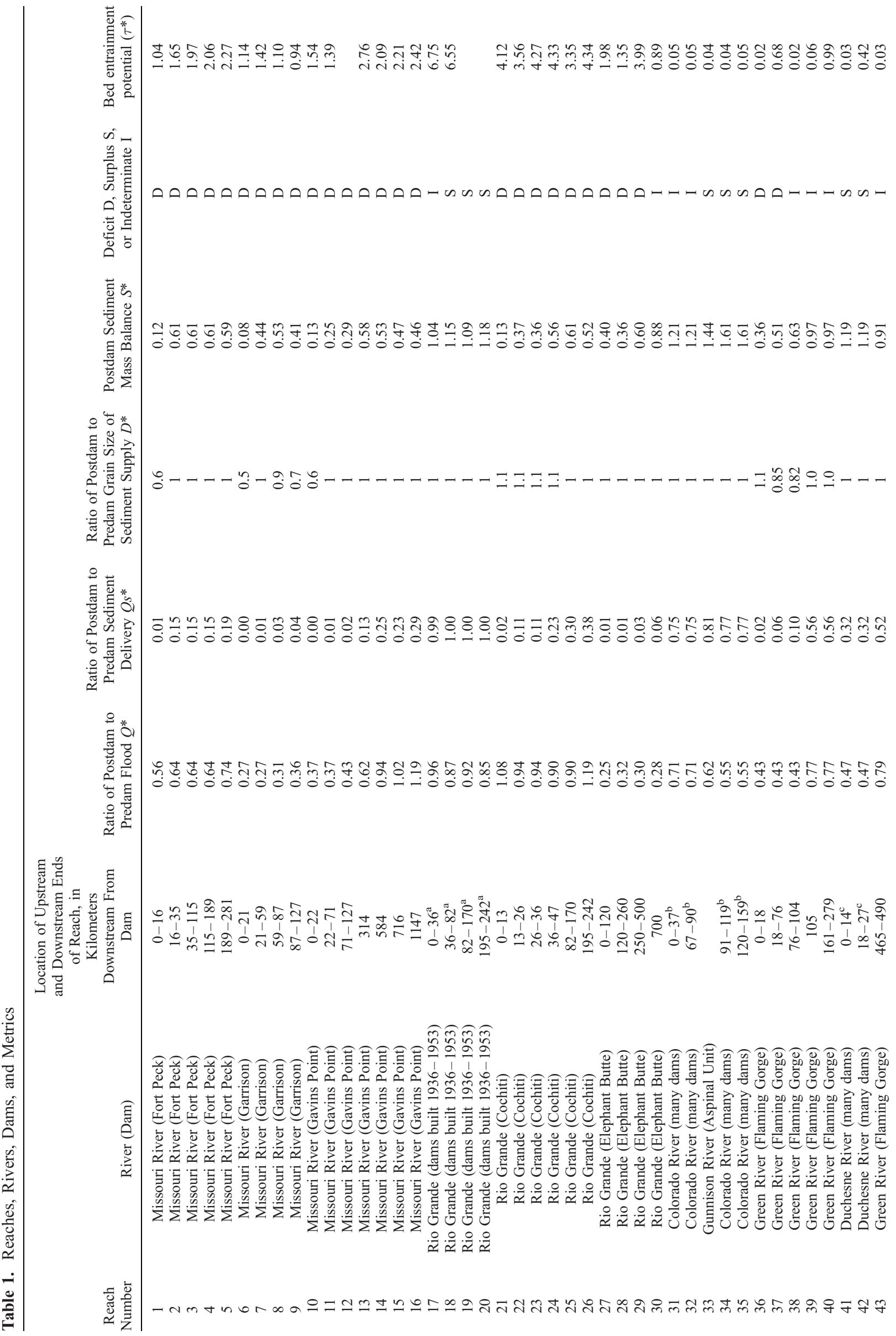




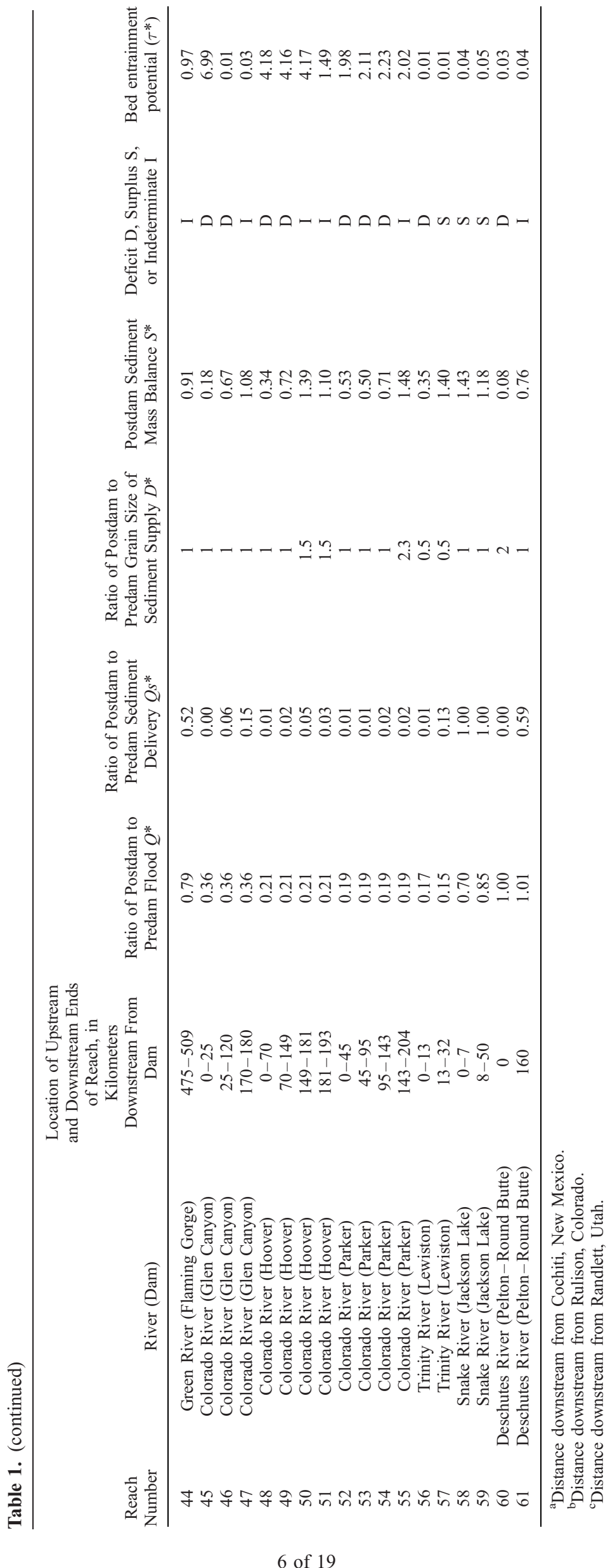


periods. One period evaluated the impact of dams constructed prior to the 1950s, and the other period allowed evaluation of the impact of Cochiti Dam, completed in 1973, through 1992 when more recently completed facilities complicate the patterns of channel change. In the case of the Rio Grande between Elephant Butte Dam and Fort Quitman, TX, we ended the postdam period in 1932, because extensive channelization and levee construction occurred thereafter. Similarly, the Colorado River downstream from Hoover Dam was channelized near Needles and Topock, CA, in the 1960s.

\subsection{Hydrology}

[23] We used the 2-year recurrence flood, $Q_{2}$, to represent $Q^{*}$ in (12), as well as for calculating the magnitude of flood reduction (Tables $2 \mathrm{a}$ and $2 \mathrm{~b}$ ). Where not available from published sources, $Q_{2}$ was computed for the most upstream gauging station within the reach. We considered changes in the 2-year flood to be a surrogate for changes in the entire flow regime [Magilligan et al., 2003], although others have advocated analysis of changes in mean annual discharge [Brandt, 2000a], bankfull discharge [Brandt, 2000a] or the duration that flows exceed the threshold of entrainment of a reference grain size [Grant et al., 2003]. Use of one flow statistic obviously simplifies the complexity of actual dam releases that may include a range of different flows, including an initial period of sustained low flows for reservoir filling, high releases due to high runoff into full reservoirs, daily and seasonal cycles associated with hydroelectric energy production or downstream water demands, and extractions of streamflow for irrigation or transbasin diversion [Richter et al., 1996; Topping et al., 2003; White et al., 2005].

\subsection{Sediment Supply}

[24] We used the mean annual sediment supply, Qs, in (12). There is wide variation in the precision and nature of sediment supply data. In the cases of the Missouri River downstream from Garrison Dam, Green River downstream from Flaming Gorge Dam, and the Colorado River downstream from Glen Canyon Dam, annual average tributary loads, as well as the loads at main stem gauges, were calculated and the average annual sediment supply is explicitly known. In other cases, only the average annual load at a gauge at the upstream end of the reach is known, and we assumed no significant sediment supply from ungauged tributaries. In these cases, we could not distinguish between sediment delivered by upstream tributaries and sediment evacuated from the channel upstream from the reach. Sediment supplied from tributaries determines the long-term sediment mass balance, but sediment supplied from main stem evacuation represents a complex, downstream-migrating transient condition. In a few cases, the absolute values of supply are not known, but the ratio of postdam to predam sediment supply could be estimated.

[25] The estimates of postdam sediment mass balance are for total or suspended load and generally refer to sand and finer sizes. Although suspended load data are often used to assess channel change [Nash, 1994], change in suspended load does not fully capture the cause of channel change where the bed is coarse, even where bed material load comprises a small proportion of the total load. None of the data are explicitly for bed material load.

[26] Estimates of sediment loads are generally imprecise, and we conducted no new analyses of these estimates. For example, published estimates of the predam annual suspended sediment load of the Green River at Jensen, UT [Andrews, 1986; Grams and Schmidt, 2002, 2005], vary $\pm 6.5 \%$. Estimates of postdam annual suspended sediment loads at the same gauge vary $\pm 2 \%$. Published estimates of total suspended loads at Green River, UT, have greater uncertainty. Thompson's [1984] estimate of the predam load, $17.7 \times 10^{6} \mathrm{Mg} / \mathrm{a}$, is $15 \%$ greater than Andrews' [1986] estimate for the same period, but Thompson's [1984] estimate of the postdam load is $1.5 \%$ less than that of Andrews [1986]. Horowitz [2003, Table III) demonstrated that the estimated annual suspended sediment flux of the lower Missouri River at Hermann, MO, between 1996 and 2000 varied $\pm 24 \%$ depending on which suspended sediment rating curve is used to estimate the annual load. Topping et al. [2000] and Grams and Schmidt [2005] demonstrated larger errors in estimating annual loads of the Colorado River and Green River, respectively.

[27] There are sufficient data for the Missouri River downstream from Garrison Dam [Keown et al., 1981; Berkas, 1995; Macek-Rowland, 2000; U.S. Army Corps of Engineers, 2000] and the Green River downstream from Flaming Gorge Dam [Grams and Schmidt, 2005] to estimate the average grain size of the sediment supply from tributary sediment transport measurements, weighted by the proportion supplied from each tributary and from bank erosion. In the case of the Missouri River downstream from Fort Peck [Simon et al., 1999; Biedenharn et al., 2001] and Gavins Point Dams [Biedenharn et al., 2001; WEST Consultants, 2002], the grain size of banks that are the primary sediment supply was compared with the predam bed material size that was assumed to represent the average grain size of the predam supply. In the case of reaches where aggradation had occurred, we assumed that the ratio of predam to postdam bed material size represented the proportional change in grain size of the supply. Elsewhere, we did not have data describing changes in the texture of sediment supplied to each reach, and we assumed that $D^{*}=1$. We also made this assumption where the primary supply was derived from bed incision immediately upstream, although we recognize that this is a transitory characteristic of the supply.

[28] Complex relations among dam operations, sediment supply, and sediment transport exist, and use of any unique reference grain size oversimplifies the effects of supply limitation [Topping et al., 2000] and mixed grain size on transport rates [Wilcock and Kenworthy, 2002; Curran and Wilcock, 2005]. For example, suspended sand concentration of the Colorado River downstream from Glen Canyon Dam varies over more than an order of magnitude depending on the distribution and grain size of the bed [Rubin and Topping, 2001]. The postdam sediment mass balance of the Colorado River in Grand Canyon computed from a stationary sediment transport relation and mean daily discharge indicates that a surplus of fine sediment exists during years of average dam releases, but the mass balance computed from shifting transport relations developed from instantaneous transport data demonstrates that there is actually sediment deficit [Topping et al., 2000; Rubin et al., 2002; Hazel et al., 2006].

\subsection{Channel Characteristics}

[29] Predam and postdam reach-average slopes were reported (Tables $2 \mathrm{a}$ and $2 \mathrm{~b}$ ). In some cases, these data were 


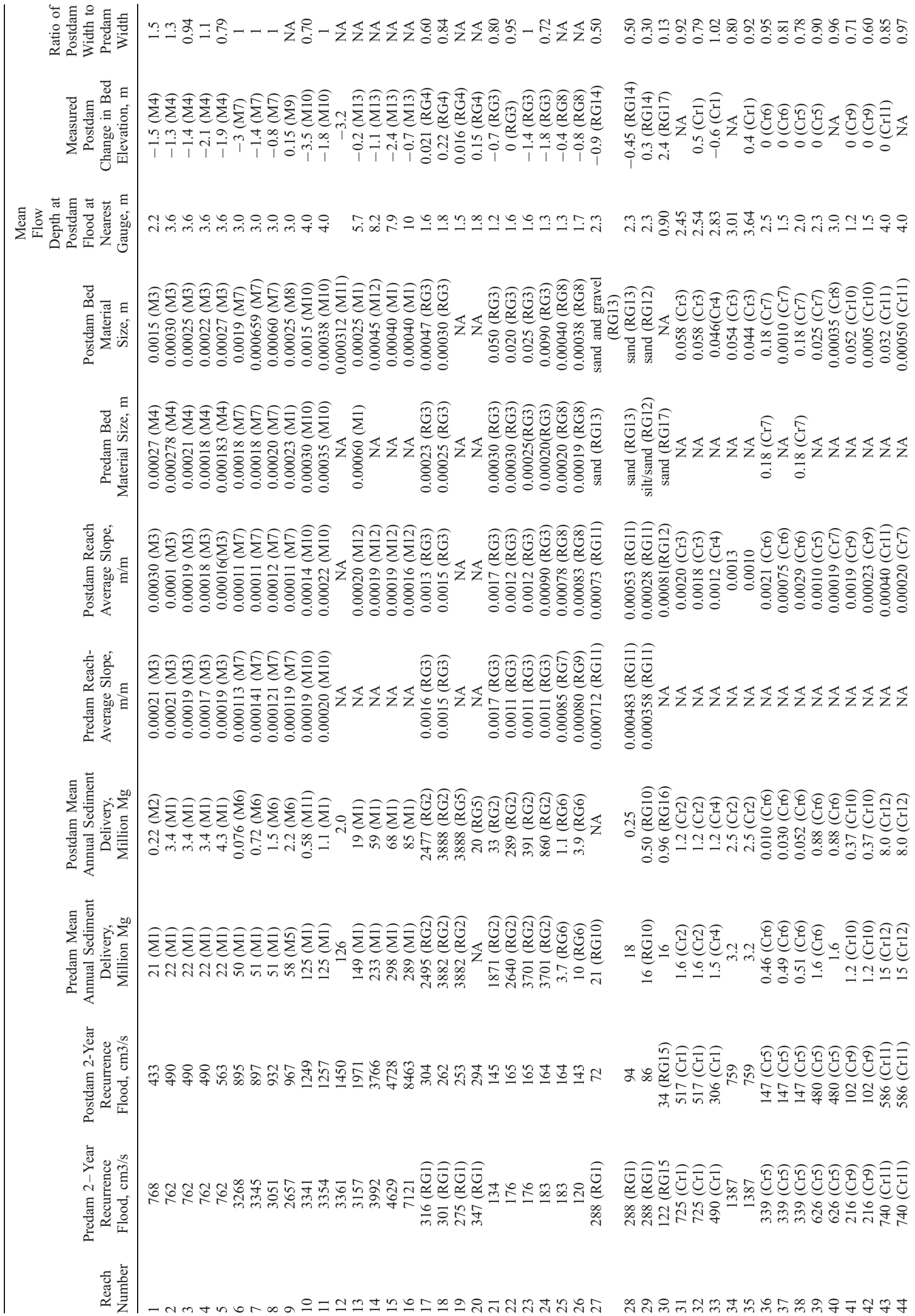




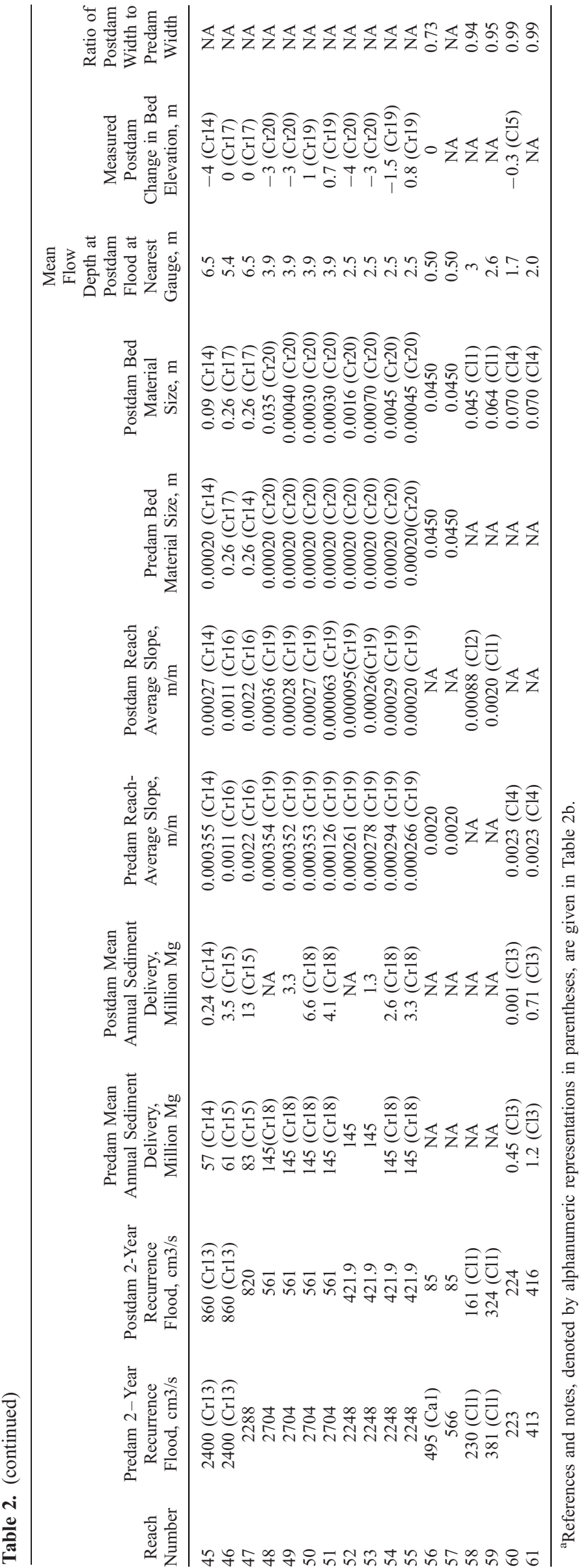


Table 2b. References and Notes for Table 2a

\begin{tabular}{|c|c|}
\hline \multicolumn{2}{|r|}{ References and Notes } \\
\hline M1 & Keown et al. [1981] \\
\hline M2 & Biedenharn et al. [2001] \\
\hline M3 & Wei $[1997]$ \\
\hline M4 & Simon et al. [1999] \\
\hline M5 & Keown et al. [1981] and Meade and Parker [1985] \\
\hline M6 & Macek-Rowland [2000] \\
\hline M7 & U.S. Army Corps of Engineers [2000] \\
\hline M8 & Berkas [1995] \\
\hline M9 & U.S. Army Corps of Engineers [2004] \\
\hline M10 & WEST Consultants $[2002]$ \\
\hline M11 & Williams and Wolman [1984, Figure 4] \\
\hline M12 & $\begin{array}{l}\text { D. Gaeuman (U.S. Geological Survey, Columbia, Missouri, } \\
\text { unpublished data, 2006) }\end{array}$ \\
\hline M13 & $\begin{array}{l}\text { Omaha, St. Joseph, Kansas City, and Hermann may be affected } \\
\text { by dredging to maintain navigation channel [U.S. Army } \\
\text { Corps of Engineers, 2004] }\end{array}$ \\
\hline RG1 & Bullard and Lane [1993] \\
\hline RG2 & Mean annual sediment concentration, in $\mathrm{mg} / \mathrm{L}$ [Richard, 2001] \\
\hline RG3 & Richard [2001] \\
\hline RG4 & $\begin{array}{l}\text { Change in elevation of channel and floodplain [Woodson and } \\
\text { Martin, 1963, Table 1] }\end{array}$ \\
\hline RG5 & Woodson and Martin [1963] \\
\hline RG6 & Graf [1994, Appendix B1] \\
\hline RG7 & Culbertson and Dawdy [1964] \\
\hline RG8 & Bauer [2000] \\
\hline RG9 & Woodson [1961] \\
\hline RG10 & Stevens $[1938]$ \\
\hline RG11 & Ainsworth and Brown [1933] \\
\hline RG12 & Stotz $[2000]$ \\
\hline RG13 & Lagasse $[1980,1981]$ \\
\hline RG14 & Stevens [1938] \\
\hline RG15 & Schmidt et al. [2003] \\
\hline RG16 & $\begin{array}{l}\text { International Boundary and Water Commission } \\
\text { [unpublished data, 1975] }\end{array}$ \\
\hline RG17 & Everitt [1993] \\
\hline $\mathrm{Cr} 1$ & Van Steeter and Pitlick [1998] \\
\hline $\mathrm{Cr} 2$ & Pitlick and Cress [2000] \\
\hline $\mathrm{Cr} 3$ & Pitlick and Cress [2002] \\
\hline $\mathrm{Cr} 4$ & Pitlick et al. [1999] \\
\hline $\mathrm{Cr} 5$ & Grams and Schmidt [2002] \\
\hline Cr6 & Grams and Schmidt [2005] \\
\hline $\mathrm{Cr} 7$ & J. C. Schmidt [unpublished data, 2006] \\
\hline $\mathrm{Cr} 8$ & Lyons et al. [1992] \\
\hline $\mathrm{Cr} 9$ & Gaeuman et al. [2005] \\
\hline $\mathrm{Cr} 10$ & Gaeuman et al. [2003] \\
\hline Cr11 & Allred and Schmidt [1999] \\
\hline $\mathrm{Cr} 12$ & Andrews [1986] \\
\hline $\mathrm{Cr} 13$ & Topping et al. [2003] \\
\hline $\mathrm{Cr} 14$ & Grams et al. [2007] \\
\hline Cr15 & Topping et al. [2000] \\
\hline Cr16 & Schmidt and Graf [1990] \\
\hline $\mathrm{Cr} 17$ & Schmidt et al. [2004] \\
\hline Cr18 & Borland and Miller [1960] \\
\hline Cr19 & U.S. Bureau of Reclamation [1950] \\
\hline $\mathrm{Cr} 20$ & Williams and Wolman [1984] \\
\hline Ca1 & $\begin{array}{l}\text { All Trinity River data (U.S. Fish and Wildlife Service and } \\
\text { Hoopa Valley Tribe, 1998; P. R. Wilcock, unpublished } \\
\text { data, 2005) }\end{array}$ \\
\hline $\mathrm{Cl1}$ & Nelson $[2007]$ \\
\hline $\mathrm{Cl} 2$ & Marston et al. $[2005]$ \\
\hline $\mathrm{Cl} 3$ & O'Connor et al. [2003, Figure 15] \\
\hline $\mathrm{Cl} 4$ & Fassnacht et al. [2003] \\
\hline $\mathrm{Cl} 5$ & $\begin{array}{l}\text { Net decrease in thalweg elevation, combining record at two } \\
\text { cross sections [Fassnacht et al., 2003, Figure 4] }\end{array}$ \\
\hline $\mathrm{Cl} 6$ & $\begin{array}{l}\text { Total area of channel and islands in entire lower Deschutes } \\
\text { River [Curran and } O^{\prime} \text { Connor, 2003, Table 5] }\end{array}$ \\
\hline
\end{tabular}

measured, and elsewhere they were computed from tables or graphs of water surface profiles. $D^{*}$ was reported for the fine grain sediment supply. $D_{B}$ was estimated as the grain size in bed features that create hydraulic controls in debris fan-affected rivers, and for the grain size of the entire bed of alluvial rivers. Mean flow depth in (14) was estimated using the postdam $Q_{2}$ from recent streamflow measurements, as reported by the U.S. Geological Survey at gauges in, or near, each reach. We represented the magnitude of measured bed incision with a single reach-averaged value for each case, consistent with the reach-scale level of the approximate analysis.

\section{Results}

\subsection{Postdam Sediment Mass Balance}

[30] Dams have caused a wide range of changes in sediment mass balance due to various combinations of change of flood magnitude and sediment supply (Figure 3). Conditions of sediment deficit or surplus are pervasive downstream from dams (Figure 4) and $0.08<S^{*}<1.61$ (Table 1). Of more than $4000 \mathrm{~km}$ of regulated river evaluated in this paper, approximately $67 \%$ is in deficit and $4 \%$ is in surplus. The lowest $S^{*}$ occurs immediately downstream from the Pelton-Round Butte complex on the Deschutes River

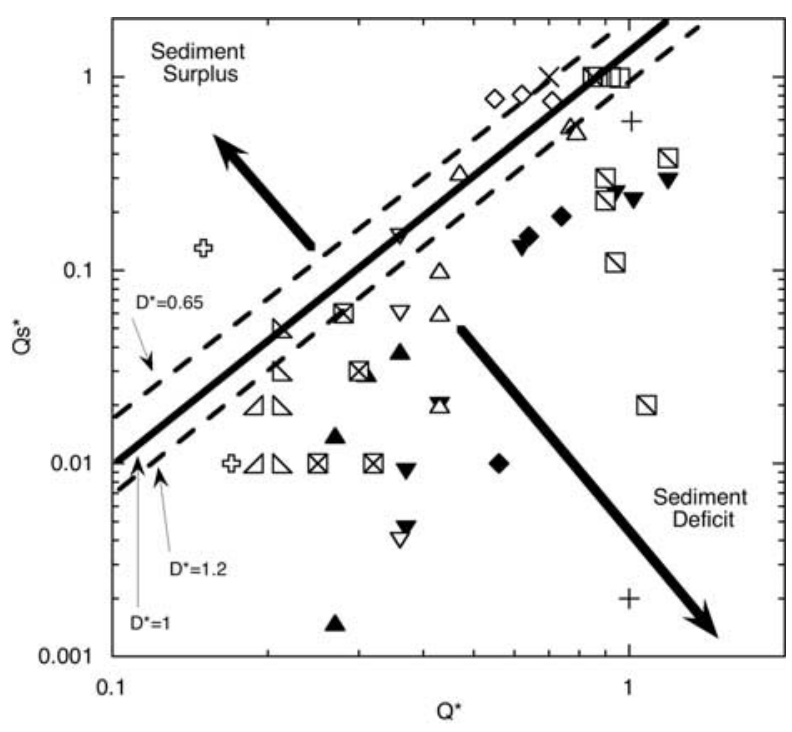

\begin{tabular}{|ll|}
\hline$\nabla$ & Missouri - Fort Peck \\
$\nabla$ & Missouri - Garrison \\
$\square$ & Rio Grande - 1950 s \\
$\nabla$ & Rio Grande - Cochiti \\
$\otimes$ & Rio Grande - Elephant Butte \\
$\diamond$ & upper Colorado \\
$\triangle$ & Green - Flaming Gorge \\
$\nabla$ & Colorado - Glen Canyon \\
$\Delta$ & Colorado - Hoover \\
$\triangle$ & Colorado - Parker \\
\& & Trinity - Lewiston \\
$\times$ & Snake - Jackson Lake \\
+ & Deschutes - Pelton Round Butte \\
\hline
\end{tabular}

Figure 3. Stability field diagram of changes in flood flow $\left(Q^{*}\right)$ and sediment supply $\left(Q s^{*}\right)$ that create sediment deficit or surplus. Diagonal lines are equilibrium conditions for $D^{*}$ of $0.65,1$, and 1.2. Individual points are the changes in sediment supply, $Q s^{*}$, and 2-year flood, $Q^{*}$, for each reach. 


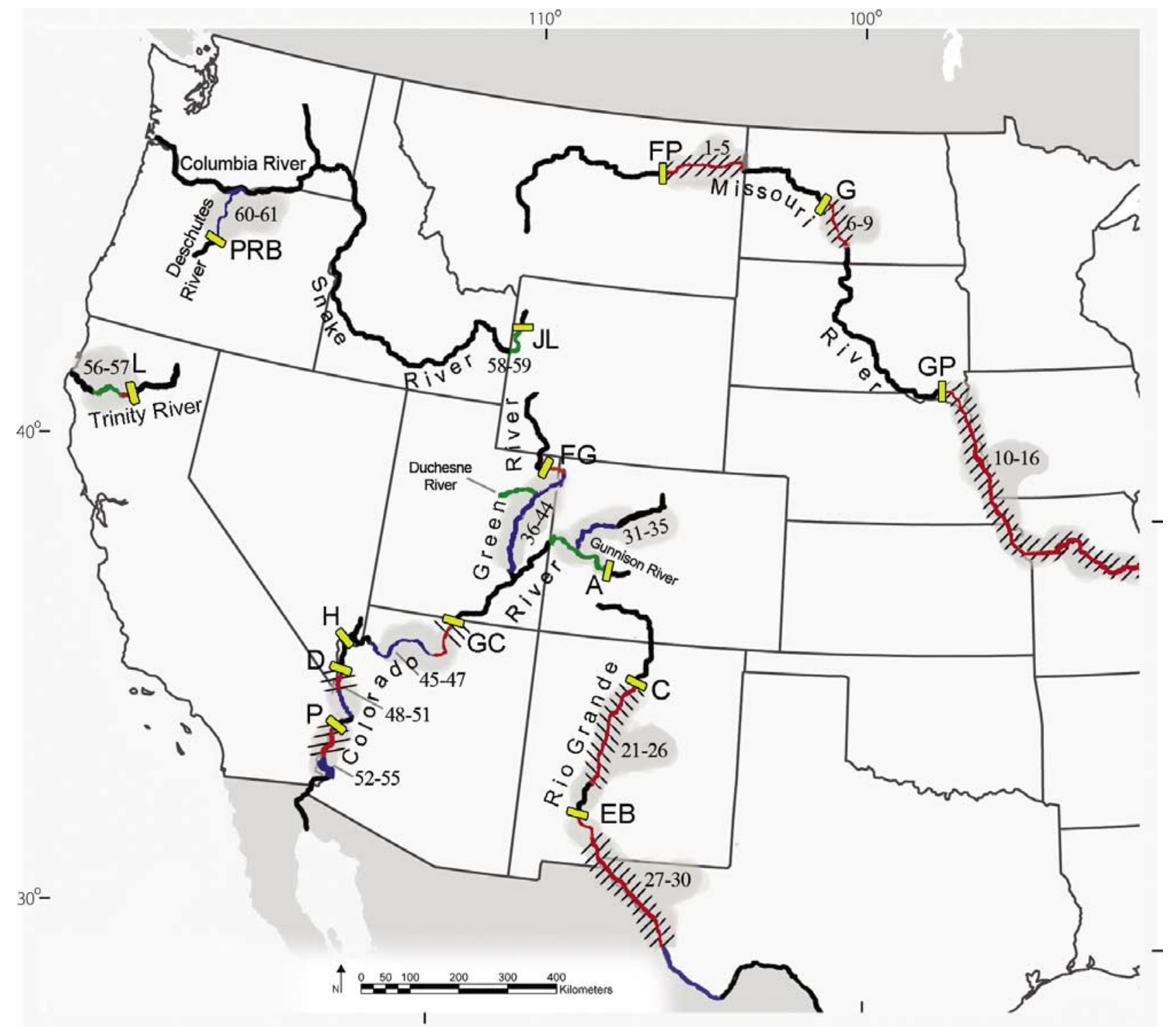

Figure 4. Location of rivers, dams, and reaches summarized in this paper. Numbers refer to reaches listed in Table 1. Red indicates reaches in sediment deficit, green indicates reaches in surplus, and blue indicates reaches where $S^{*}$ is indeterminate, as listed in Table 1. Cross-hatched reaches are those where $\tau^{*}>0.06$ and incision is likely. Dams are FP, Fort Peck; G, Garrison; GP, Gavins Point; C, Cochiti; EB, Elephant Butte; A, Aspinal Unit of three dams; FG, Flaming Gorge; GC, Glen Canyon; H, Hoover; D, Davis; P, Parker; L, Lewiston; JL, Jackson Lake; and PRB, Pelton-Round Butte complex of dams.

where the postdam flood regime is no different than the predam regime and all sediment from the upstream watershed is trapped in reservoirs (Table 1). Large deficits also occur immediately downstream from other large dams, except at Jackson Lake Dam where sediment delivery has not changed. The mass balance is in equilibrium or is indeterminate, due to uncertainty in $D^{*}$, in $29 \%$ of the evaluated river length.

[31] There is good agreement with the locations of degradation or aggradation measured in the field. In cases where there are large depletions of stream flow, such as on the Rio Grande downstream from Elephant Butte Dam, $Q^{*}$ does not adequately characterize changes in flow regime. Here, large sediment surplus is not predicted but significant aggradation has been measured [Everitt, 1993]. S* agrees well with the measured volume of sediment evacuated or accumulated downstream from Hoover and Parker Dams on the lower Colorado River (Figure 5). Degradation of the Missouri River near Bismark, ND, is predicted, but aggradation has occurred because of backwater effects of Oahe Reservoir, located immediately downstream [U.S. Army Corps of Engineers, 2004].

[32] There is good agreement between $S^{*}$ and the relatively few detailed postdam sediment budgets based on (13). Deficit conditions in the Colorado River within $100 \mathrm{~km}$ downstream from Glen Canyon Dam agree with the sediment budgets of Topping et al. [2000], Schmidt et al. [2004], and Hazel et al. [2006]. Estimates of deficit and equilibrium are also in agreement with those of Grams and 

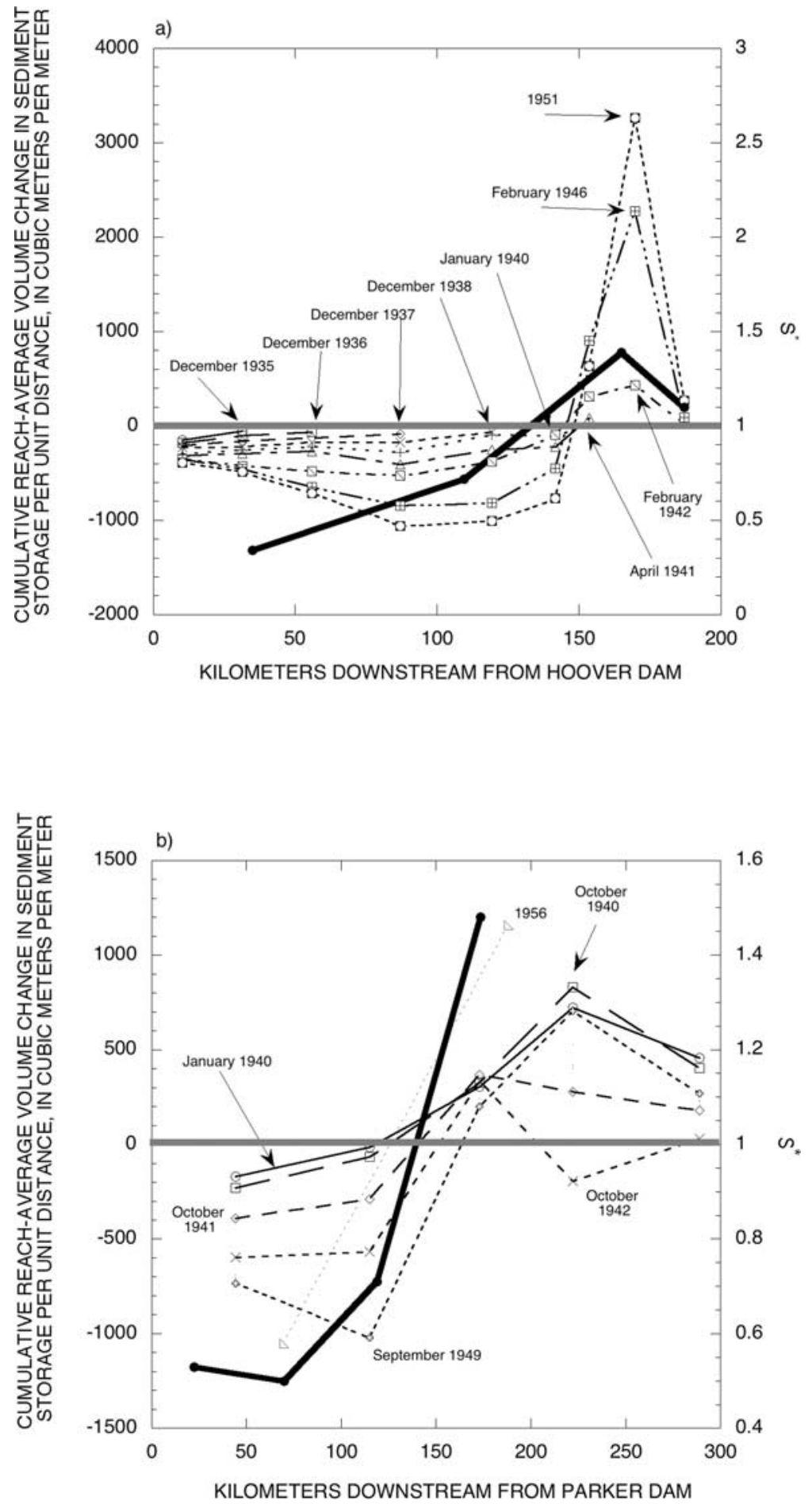

Figure 5. Cumulative degradation or aggradation between completion of (a) Hoover Dam in 1934 and (b) Parker Dam in 1937 and indicated time, as well as $S^{*}$ for the same reaches. Field data are shown in thin lines for different time periods computed from U.S. Bureau of Reclamation [1950], Stanley [1951], and Borland and Miller [1960], and the thick solid line is $S^{*}$ from (12).

Schmidt [2005] for parts of the Green River downstream from Flaming Gorge Dam.

[33] Individual dams can cause different perturbations in sediment mass balance at different locations downstream, and reaches at the same distance downstream from different dams are perturbed to different degrees (Figure 6). $S^{*}$ typically increases in the downstream direction, because
$Q s^{*}$ increases at a greater rate than $Q^{*}$. This is the situation for the Rio Grande, upper Colorado River, and Green River, where the sediment deficit is eliminated or reversed in the most downstream parts of each river. In contrast, $S^{*}$ becomes more negative on the Missouri River downstream from Gavins Point Dam, because $Q^{*}$ increases from 0.62 to 1.19 , but $Q s^{*}$ only increases from 0.13 to 0.29 . 

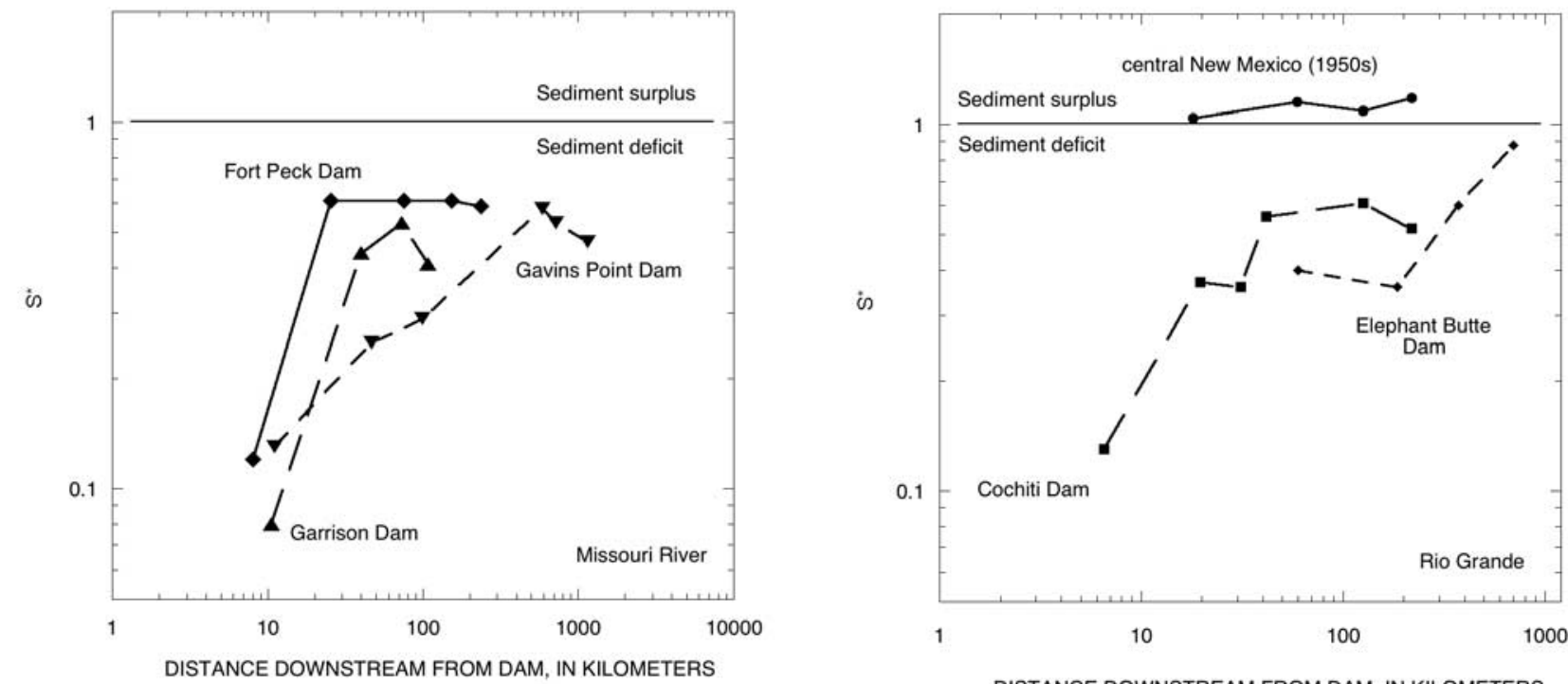

DISTANCE DOWNSTREAM FROM DAM, IN KILOMETERS
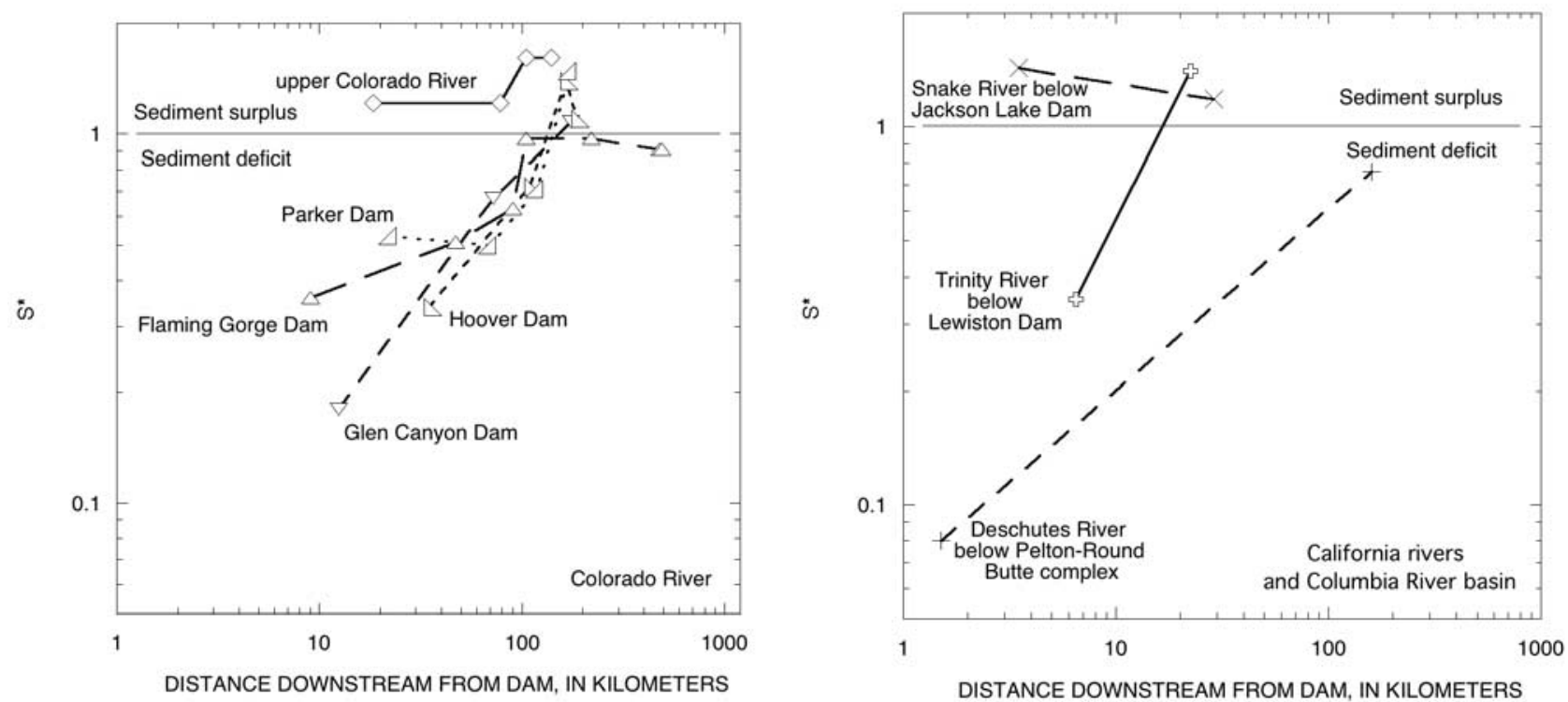

Figure 6. Downstream change in postdam sediment mass balance $\left(S^{*}\right)$. Distances downstream from dams are those for the midpoint of the reaches listed in Table 1. Symbols are the same as those in Figure 3.

[34] Sediment surplus is predicted over a wide range of $Q s^{*}$, emphasizing that the postdam sediment mass balance depends on relative changes in flow and sediment supply. Surplus conditions occur on part of the Trinity River, where $Q s^{*}=0.13$, and $Q^{*}=0.15$. Surplus conditions also occur on parts of the upper Colorado, Gunnison, and Snake Rivers where $0.75<Q s^{*}<1$ and $0.55<Q^{*}<0.85$.

[35] In a few cases, $Q^{*}>1$. These circumstances occur on part of the Rio Grande downstream from Cochiti Dam and on the most downstream part of the lower Missouri River (Table 1). Although not evaluated here, this ratio is also greater than one where streamflow is augmented by trans- basin diversions [Kellerhals et al., 1979]. Since augmentation of sediment is not known to occur in coordination with flow augmentation, examination of (12) and Figure 3 indicates that all flow-augmented streams must be in sediment deficit.

\subsection{Bed Incision Potential}

[36] The metric $\tau^{*}$ indicates the potential for bed incision. Under conditions of deficit, significant incision has occurred where $\tau^{*}>0.1$ and $S^{*}>1$. Insignificant incision has occurred where $\tau^{*}<0.1$ (Figure 7). The magnitude of bed incision for large values of $\tau^{*}$ is highly variable, because of differences in substrate, time since dam comple- 
a)

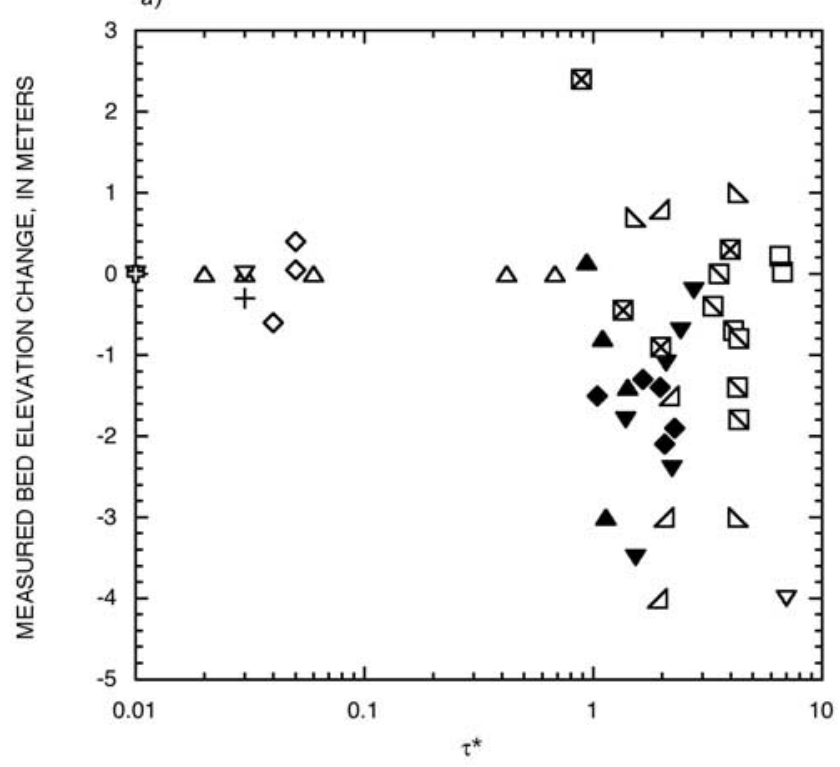

b)

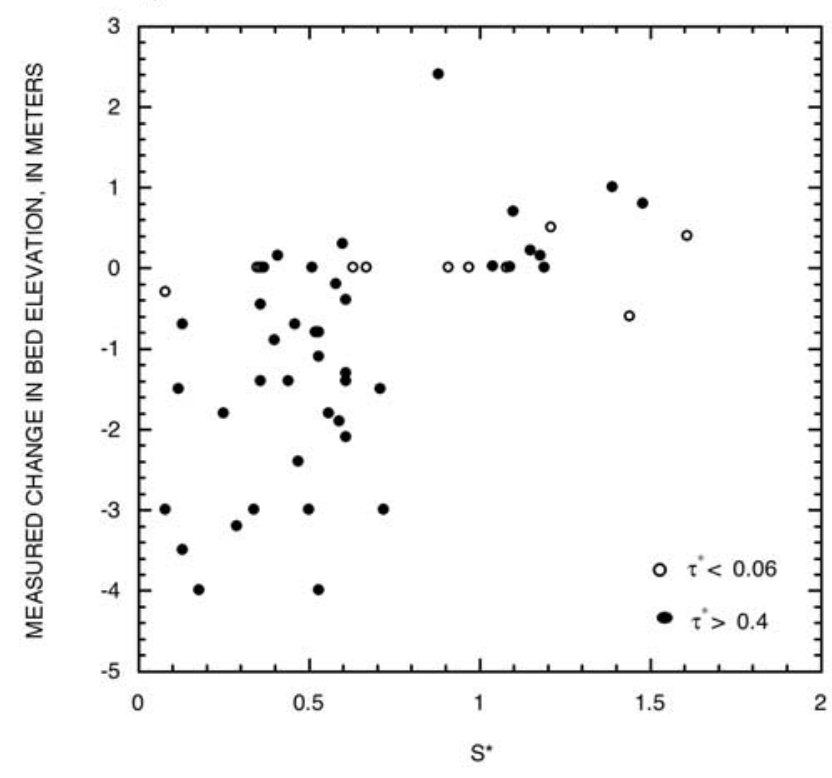

Figure 7. Measured average change in bed elevation as a function of (a) $\tau^{*}$ and (b) $S^{*}$. Values of $\tau^{*}$ have a bimodal distribution. Approximately $25 \%$ of the reaches have $\tau^{*}<$ 0.1 , and $\tau^{*}>0.1$ for other reaches. Values of $S^{*}<1$ and $\tau^{*}>0.4$ are necessary, but not sufficient, to produce significant bed incision. Other factors include the duration, magnitude, and frequency of postdam flows capable of moving substantial amounts of sediment. In Figure 7a, symbols are the same as those used in Figure 3. In Figure $7 \mathrm{~b}$, symbols distinguish between $\tau^{*}<0.06$ and $\tau^{*}>0.4$.

tion, and magnitude of dam releases [Williams and Wolman, 1984].

[37] Distinction between reaches subject to incision and those where incision has not occurred is consistent with published observations on the Rio Grande [Lagasse, 1981] and lower Colorado Rivers [Stevens, 1938]. Even under conditions of severe sediment deficit, incision has not occurred where the bed is very coarse, such as the debris fan-affected part of the Green River immediately downstream from Flaming Gorge Dam [Grams and Schmidt, 2005] and in the debris fan-affected Colorado River in Grand Canyon beginning approximately $25 \mathrm{~km}$ downstream from Glen Canyon Dam. In fact, aggradation of coarse sediment has occurred in some of Grand Canyon's rapids [Howard and Dolan, 1981; Magirl et al., 2005], even though $S^{*}<1$ for fine sediment. In contrast to the relatively short distance over which incision has occurred downstream from Glen Canyon Dam, incision occurred far downstream on streams where $S^{*}<1$ and where the predam bed was sand, such as on the Missouri River, throughout most of the Rio Grande in central New Mexico, and on the lower Colorado River.

\subsection{Flood Reduction}

[38] The range in $Q^{*}$ is wide, $0.15<Q^{*}<1.19$, consistent with the many purposes of dams; Magilligan and Nislow [2005] reported an even wider range. No consistent trend is evident between channel narrowing and $Q^{*}$ (Figure 8a), although extreme narrowing to less than $60 \%$ of the predam width is observed only where $Q^{*}<0.4$. Also, the greatest degree of channel narrowing has occurred where $\tau^{*}>0.1$, suggesting that significant channel narrowing also occurs where beds significantly incise (Figure 8b). Variability in the magnitude of channel narrowing is due to many factors, including the time available for inset floodplains to form and the availability of a postdam fine sediment supply with which to build a new floodplain. There may not be any fine sediment available for postdam floodplain formation immediately downstream from some dams. In these cases, channel width is mostly determined by geotechnical properties of the valley alluvium [Shields et al., 2000].

\section{Reversing Undesired Conditions}

[39] Although some degree of channel change may be considered an acceptable cost of water development, large amounts of degradation or aggradation, bed incision, or channel narrowing are clearly undesirable in some situations and become the focus of river rehabilitation efforts. This is especially the case where the regulated river segments are relatively long, retain significant natural resources, are not channelized or leveed, are designated as critical endangered species habitat, are designated as wild or scenic, or cross units of the National Park Service. This is the case in parts of the Missouri River and Rio Grande, throughout the Colorado River basin upstream from Hoover Dam, on the Trinity River, the Snake River, and the Deschutes River.

[40] The national scope, investment, and need to prioritize rehabilitation of large, regulated rivers provide incentive to compare the effort necessary to reverse undesired channel conditions downstream from dams. Regional comparisons are especially important where the costs of several rivers targeted for rehabilitation are paid by the same power consumers or taxpayers. This is the case for many of the dams in the western United States, because the hydroelectricity produced at these dams is linked by an integrated transmission system and the same pool of ratepayers. Thus, it may be useful to ask where investment in river rehabilitation will give the greatest return. Might the same effort 
a)

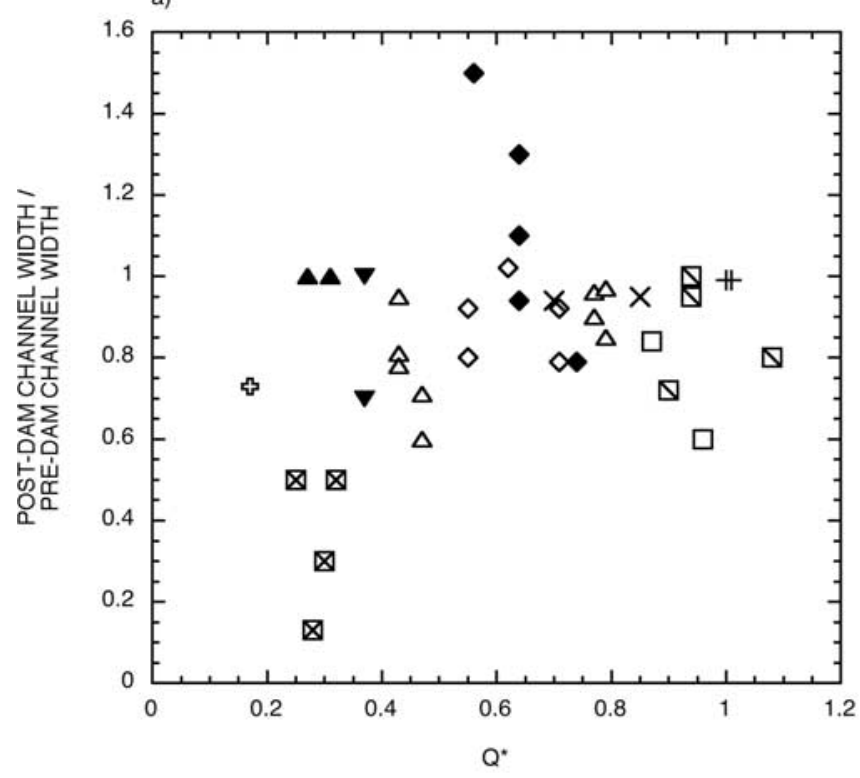

b)

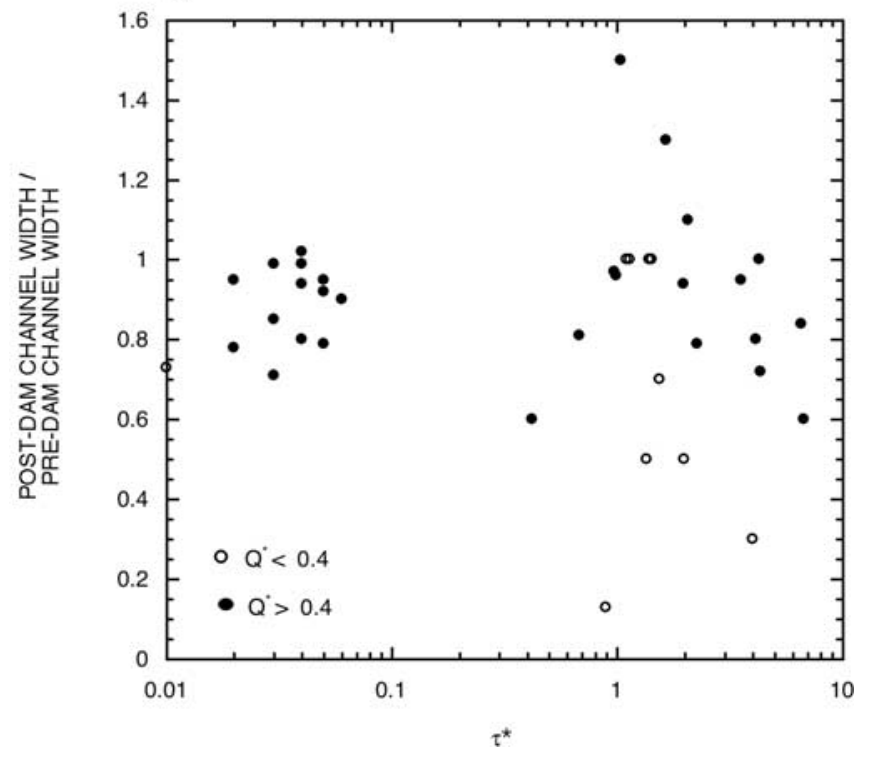

Figure 8. Average change in channel width as a function of (a) $Q^{*}$ and (b) $\tau^{*}$. Small values of $Q^{*}(<0.4)$ and large values of $\tau^{*}(>0.4)$ are necessary, but not sufficient, requirements for very large $(>50 \%)$ reduction of channel width. Other factors include the availability of riparian vegetation for colonization of new floodplain deposits and the timing and frequency of postdam flows capable of preventing inchannel establishment of vegetation. In Figure 8a, symbols are the same as those used in Figure 3. In Figure 8b, symbols distinguish between $Q^{*}<0.4$ and $Q^{*}>0.4$.

achieve a greater degree of rehabilitation in some places rather than others?

[41] There are three general strategies to reverse undesired channel conditions: changing the release pattern of water, altering the supply of downstream sediment, and physically manipulating the downstream channel and/or its riparian vegetation. Each strategy includes a range of practices that have been implemented with varying degrees of enthusiasm, cost, and frequency, and the mix of strategies depend on whether the postdam sediment mass balance is sediment deficit or surplus.

[42] The postdam sediment mass balance defined in (12) provides a basis with which to assess the relative effort of remediating deficit or surplus in different reaches. There is an infinite combination of possibilities whereby augmentation of the sediment supply and increase of the flood regime would achieve postdam sediment mass balance. Strategies that increase flood flows to rivers in sediment surplus or that add sediment to rivers in deficit rehabilitate regulated rivers toward their predisturbance, or wild, condition (Figure 9). Strategies that decrease sediment supply to rivers in surplus or decrease flood flows to rivers in deficit shift regulated rivers toward miniaturized conditions. Because native riverine ecosystems depend on a range of attributes of natural hydrographs [Poff et al., 1997], shifting a river into postdam sediment balance while also shifting the flow regime toward its predisturbance scale is desirable where rehabilitation of native ecosystems is desired.

[43] We assessed the relative magnitude of prescriptive actions whose goals are to achieve postdam sediment mass balance and also to avoid further channel minimization. Thus, we estimated the proportional increase in sediment supply or flood flows necessary to return each reach to postdam sediment equilibrium along paths indicated by solid lines in Figure 9. Estimates were made by adjusting the value of $Q^{*}$ or $Q s^{*}$ in (12) such that $S^{*}=1$.

[44] The proportional increase in sediment supply necessary to reverse deficit is quite large in many cases and

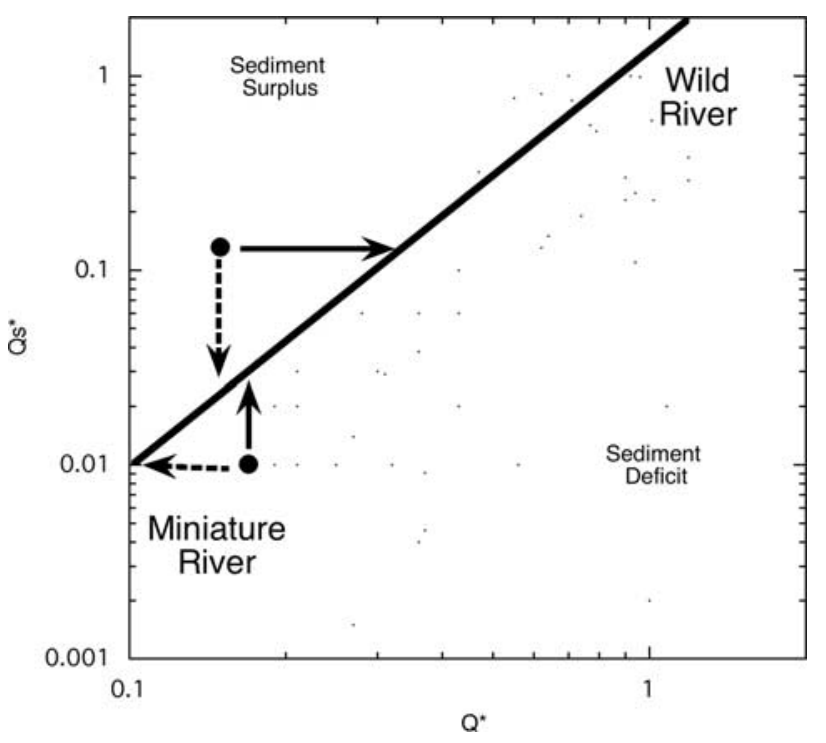

Figure 9. Stability field diagram of changes in flood flow and sediment supply that create sediment deficit or surplus. Black circles are hypothetical reaches in deficit and surplus. Solid arrows indicate change in sediment supply or flood regime necessary to return reach to postdam sediment mass balance and whose trajectory shifts the river toward predisturbance conditions. Dashed arrows indicate change in sediment supply or flood regime whose trajectory shifts the river toward further miniaturization. 
Table 3. Proportional Changes in Sediment Supply or Magnitude of 2-Year Flood Necessary to Achieve Postdam Equilibrium Sediment Mass Balance $S^{*}=1$

\begin{tabular}{|c|c|c|c|c|}
\hline & $\begin{array}{l}\text { Ratio of Postdam to } \\
\text { Predam Sediment Supply } \\
\text { Necessary for Equilibrium } \\
\text { Mass Balance Conditions, } \\
\text { Assuming No Change in } \\
\text { Flood Regime }\end{array}$ & $\begin{array}{l}\text { Proportional Increase } \\
\text { in Postdam Sediment } \\
\text { Supply Needed to } \\
\text { Achieve Equilibrium } \\
\text { Mass Balance }\end{array}$ & $\begin{array}{l}\text { Ratio of Postdam to } \\
\text { Predam Flood } \\
\text { Conditions } \\
\text { Necessary for } \\
\text { Equilibrium Mass } \\
\text { Balance Conditions }\end{array}$ & $\begin{array}{l}\text { Proportional Change } \\
\text { in Postdam Flood } \\
\text { Flows Needed to } \\
\text { Achieve } \\
\text { Equilibrium Mass } \\
\text { Balance }\end{array}$ \\
\hline $\begin{array}{l}\text { Missouri River, } 16-115 \mathrm{~km} \\
\text { downstream from Fort } \\
\text { Peck Dam (reaches } 2 \\
\text { and 3) }\end{array}$ & 0.41 & 1.7 & 0.4 & -0.4 \\
\hline $\begin{array}{l}\text { Missouri River, } 21-59 \mathrm{~km} \\
\text { downstream from } \\
\text { Garrison Dam } \\
\text { (reach 7) }\end{array}$ & 0.1 & 4 & 0.1 & -0.6 \\
\hline $\begin{array}{l}\text { Missouri River, } 22-71 \mathrm{~km} \\
\text { downstream from } \\
\text { Gavins Point Dam (reach 11) }\end{array}$ & 0.14 & 14.4 & 0.1 & -0.7 \\
\hline $\begin{array}{l}\text { Rio Grande, } 13-26 \mathrm{~km} \\
\text { downstream from } \\
\text { Cochiti Dam } \\
\text { (reach 22) }\end{array}$ & 0.8 & 6.5 & 0.3 & -0.6 \\
\hline $\begin{array}{l}\text { Colorado River, } 91-119 \mathrm{~km} \\
\text { downstream from } \\
\text { Rulison, CO (reach 34) }\end{array}$ & 0.3 & -0.6 & 0.9 & 0.6 \\
\hline $\begin{array}{l}\text { Green River, } 18-76 \mathrm{~km} \\
\text { downstream from } \\
\text { Flaming Gorge Dam } \\
\text { (reach 37) }\end{array}$ & 0.24 & 2.9 & 0.2 & -0.5 \\
\hline $\begin{array}{l}\text { Colorado River, } 25-120 \mathrm{~km} \\
\text { downstream from } \\
\text { Glen Canyon Dam } \\
\text { (reach 46) }\end{array}$ & 0.13 & 1.2 & 0.24 & -0.3 \\
\hline $\begin{array}{l}\text { Colorado River, } 70-149 \mathrm{~km} \\
\text { downstream from } \\
\text { Hoover Dam (reach 49) }\end{array}$ & 0.04 & 0.9 & 0.2 & -0.3 \\
\hline $\begin{array}{l}\text { Colorado River, } 45-95 \mathrm{~km} \\
\text { downstream from } \\
\text { Parker Dam (reach 53) }\end{array}$ & 0.04 & 2.9 & 0.1 & -0.5 \\
\hline $\begin{array}{l}\text { Trinity River, } 13-32 \mathrm{~km} \\
\text { downstream from } \\
\text { Lewiston Dam } \\
\text { (reach 57) }\end{array}$ & 0.06 & -0.5 & 0.2 & 0.4 \\
\hline $\begin{array}{l}\text { Snake River, } 8-50 \mathrm{~km} \\
\text { downstream from } \\
\text { Jackson Lake Dam } \\
\text { (reach 59) }\end{array}$ & 0.7 & -0.3 & 1 & 0.2 \\
\hline $\begin{array}{l}\text { Deschutes River, } 160 \mathrm{~km} \\
\text { downstream from } \\
\text { Pelton-Round } \\
\text { Butte complex (reach 61) }\end{array}$ & 1 & 0.7 & 0.8 & -0.2 \\
\hline
\end{tabular}

ranges between 70 and 1,440\% (Table 3). The proportional increase in flood magnitudes appropriate for reversal of sediment surplus is smaller, between 20 and $60 \%$, but there are fewer of these reaches. Where the magnitude of change in flood regime to reverse sediment surplus is relatively small, these changes may be achievable without changing the reservoir release infrastructure of the dam. The costs of increasing flood magnitude are probably smaller than the costs of sediment augmentation, because increased flood flows commonly can be accommodated without redesign of reservoir release structures. Nevertheless, reintroduction of flood flows involves loss of some hydroelectric power production.

[45] Many deficit segments require large proportional increases in sediment delivery. Typically, significant infrastructure changes are necessary to implement this manage- ment option. For example, application of (12) to the Colorado River in Grand Canyon indicates that augmenting the postdam annual fine sediment supply with an additional $7.9 \times 10^{6} \mathrm{Mg} / \mathrm{a}$ would eliminate deficit conditions with no change in the flood regime. This amount of augmented sediment would only increase $Q s^{*}$ to 0.13 . This ratio is small, because the magnitude of postdam floods has been reduced approximately $60 \%$. This amount of sediment is nevertheless large in terms of engineering design. Randle et al. [2007] estimated that augmentation of $4.3 \times 10^{6} \mathrm{Mg} / \mathrm{a}$ to the Colorado River in Grand Canyon would cost between $\$ 220$ to $\$ 430 \times 10^{6}$ in project capital costs and between $\$ 6.6$ and $\$ 17 \times 10^{6} / \mathrm{a}$ in annual operating costs. In comparison, the 7-day release of a controlled flood from Glen Canyon Dam in 1996 had an economic cost of $\$ 2.5 \times 10^{6}$, 
which was $3.3 \%$ of the economic value of the hydroelectric power produced in that year [Harpman, 1999].

\section{Conclusions}

[46] Metrics of the key environmental drivers of channel change allow regional identification of factors controlling channel change. The fundamental cause of channel change is the imbalance between sediment supply and stream flow, leading to conditions of postdam sediment deficit or surplus. Under conditions of sediment deficit, channel incision can occur, but only if the postdam regime is competent, which we quantify with a Shields number. Long-term changes in channel width and the rate at which the sediment balance is reequilibrated may be related to the ratio of postdam to predam flood discharge.

[47] Of more than $4000 \mathrm{~km}$ of regulated rivers evaluated in this paper, more than $60 \%$ is in sediment deficit, thereby causing degradation. The spatial distribution of deficit and surplus reaches is primarily determined by the distance between dams and downstream tributaries that significantly alter the postdam flood and sediment supply regime. The effort of rehabilitating deficit segments via sediment augmentation may exceed those of rehabilitating surplus segments via reintroduction of floods.

[48] Our analysis is nevertheless incomplete and must be augmented by a variety of other considerations before making decisions about restoration priorities. Of primary importance is the location of valued ecological or social resources, which may substantially alter economic or political assessment of our analysis. Other factors, such as the location of highly valued resources, the extent of postdam incision, the along-stream variation in water and sediment supply and channel change, and the colonization of native and nonnative riparian vegetation must be considered when evaluating individual rivers and specific river management opportunities. In some locations, details of the changed physical structure of channels may of great ecological consequence. Elsewhere, regulatory obligations or public values may dictate an effort toward full restoration, despite daunting constraints.

[49] A regional or national comparison of the magnitude of disturbance downstream from dams on large rivers can provide a rational basis for assessing and prioritizing the outcomes, costs, and benefits of different river management alternatives. The United States is a wealthy country with many magnificent rivers worthy of focused environmental management, but there are not sufficient funds, nor political consensus, to fully restore every river. The scientific community is obligated to present a template for regional prioritization and tradeoffs if limited resources are to be expended wisely.

[50] Acknowledgments. The authors extend their thanks for insightful and careful reviews by Gordon Grant, Philip Kaufmann, Frank Magilligan, and Jim O'Connor. Assembly of the various data describing river conditions could not have been completed without the help of numerous friendly and supportive colleagues, including Ben Everitt, David Gaeuman, Paul Grams, Rob Jacobson, Carter Johnson, Darren Olsen, John Pitlick, Gigi Richard, and Andrew Simon. This work was supported in part by the Intermountain Center for River Rehabilitation and Restoration at Utah State University and by the STC program of the National Science Foundation via the National Center for Earth-surface Dynamics under the agreement EAR0120914.

\section{References}

Ainsworth, C. M., and F. P. Brown (1933), Report on the changes in regimen of the Rio Grande in the valleys below since the construction of Elephant Butte Dam 1917-1932, unpublished report, 84 pp., Int. Boundary Comm., Washington, D. C.

Allred, T. M., and J. C. Schmidt (1999), Channel narrowing by vertical accretion along the Green River near Green River, Utah, Geol. Soc. Am. Bull., 111, 1757-1772.

Andrews, E. D. (1986), Downstream effects of Flaming Gorge Dam on the Green River, Colorado and Utah, Geol. Soc. Am. Bull., 97, 1012-1023.

Bauer, T. R. (2000), Morphology of the middle Rio Grande from Bernalillo Bridge to the San Acacia diversion dam, New Mexico, thesis, M.S., 308 pp., Colo. State Univ., Fort Collins, Colo.

Berkas, W. R. (1995), Transport and sources of sediment in the Missouri River between Garrison Dam and the headwaters of Lake Oahe, North Dakota, May 1988 through April 1991, U.S. Geol. Surv. Water Resour. Invest. Rep. 95-4087, 26 pp.

Biedenharn, D. S., R. S. Soileau, L. C. Hubbard, P. H. Hoffman, C. R. Thorne, C. C. Bromley, and C. C. Watson (2001), Missouri River-Fort Peck Dam to Ponca State Park geomorphological assessment related to bank stabilization, 139 pp., Omaha Distr., U.S. Army Corps of Eng., Omaha, Nebr.

Borland, W. M., and C. R. Miller (1960), Sediment problems of the lower Colorado River, Proc. Am. Soc. Civ. Eng. J. Hydraul. Div., 86(4), $61-87$.

Brandt, S. A. (2000a), Classification of geomorphological effects downstream of dams, Catena, 40, 375-401.

Brandt, S. A. (2000b), Prediction of downstream geomorphological changes after dam construction: A stream power approach, Water Resour. Dev., 16, 343-367.

Bullard, K. L., and W. L. Lane (1993), Middle Rio Grande peak flow frequency study, report, Flood Hydrol. Group, Bur. of Reclam., Tech. Serv. Cent., U.S. Dep. of the Inter., Albuquerque, N. M.

Carling, P. A. (1988), Channel change and sediment transport in regulated rivers U.K., Regul. Rivers Res. Manage., 2, 369-388.

Culbertson, J. K. and D. R. Dawdy (1964), A study of fluvial characteristics and hydraulic variables, middle Rio Grande, New Mexico, U.S. Geol. Surv. Water Supply Pap., 1498-F, 74 pp.

Curran, J. C., and P. R. Wilcock (2005), The effect of sand supply on transport rates in a gravel-bed channel, J. Hydraul. Eng., 131(11), 961, doi:10.1061/ (ASCE)0733-9429.

Curran, J. H., and J. E. O'Connor (2003), Formation and evolution of valley-bottom and channel features, lower Deschutes River, Oregon, in A Peculiar River: Geology, Geomorphology, and Hydrology of the Deschutes River, Oregon, Water Sci. Appl., vol. 7, edited by J. E. O’Connor and G. E. Grant, pp. 95-119, AGU, Washington, D. C.

Everitt, B. (1993), Channel response to declining flow on the Rio Grande between Ft. Quitman and Presidio, Texas, Geomorphology, 6, 225242.

Fassnacht, H., E. M. McClure, G. E. Grant, and P. C. Klingeman (2003), Downstream effects of the Pelton-Round Butte hydroelectric project on bedload transport, channel morphology, and channel-bed texture, lower Deschutes River, Oregon, in A Peculiar River: Geology, Geomorphology, and Hydrology of the Deschutes River, Oregon, Water Sci. Appl., vol. 7, edited by J. E. O’Connor and G. E. Grant, pp. 169-201, AGU, Washington, D. C.

Gaeuman, D. A., J. C. Schmidt, and P. R. Wilcock (2003), Evaluation of inchannel gravel storage with morphology-based gravel budgets developed from planimetric data, J. Geophys. Res., 108(F1), 6001, doi:10.1029/ 2002JF000002.

Gaeuman, D. A., J. C. Schmidt, and P. R. Wilcock (2005), Complex channel responses to changes in stream flow and sediment supply on the lower Duchesne River, Utah, Geomorphology, 64, 185-206.

Graf, W. L. (1994), Plutonium and the Rio Grande, 329 pp., Oxford Univ. Press, New York.

Grams, P. E., and J. C. Schmidt (1999), Geomorphology of the Green River in the eastern Uinta Mountains, Dinosaur National Monument, Colorado and Utah, in Varieties of Fluvial Form, edited by A. J. Miller and A. Gupta, pp. 81-111, John Wiley, Hoboken, N. J.

Grams, P. E., and J. C. Schmidt (2002), Streamflow regulation and multilevel floodplain formation: Channel narrowing on the aggrading Green River in the eastern Uinta Mountains, Colorado and Utah, Geomorphology, 44, 337-360.

Grams, J. C., and J. C. Schmidt (2005), Equilibrium or indeterminant? Where sediment budgets fail: Sediment mass balance and adjustment of channel form, Green River downstream from Flaming Gorge Dam, Utah and Colorado, Geomorphology, 71, 156-181. 
Grams, P. E., J. C. Schmidt, and D. J. Topping (2007), The rate and pattern of bed incision and bank adjustment on the Colorado River in Glen Canyon downstream from Glen Canyon Dam, 1956-2000, Geol. Soc. Am. Bull., 119, 556-575.

Grant, G. E., J. C. Schmidt, and S. L. Lewis (2003), A geological framework for interpreting downstream effects of dams on rivers, in A Peculiar River: Geology, Geomorphology, and Hydrology of the Deschutes River, Oregon, Water Sci. Appl., vol. 7, edited by J. E. O'Connor and G. E. Grant, pp. 203-219, AGU, Washington, D.C.

Harpman, D. A. (1999), The economic cost of the 1996 controlled flood, in The Controlled Flood in Grand Canyon, Geophys. Monogr. Ser., vol. 110, edited by R. H. Webb et al., pp. 351-357, AGU, Washington, D.C.

Hazel, J. E., Jr., D. J. Topping, J. C. Schmidt, and M. Kaplinski (2006), Influence of a dam on fine-sediment storage in a canyon river, J. Geophys. Res., 111, F01025, doi:10.1029/2004JF000193.

Henderson, F. W. (1966), Open Channel Flow, 522 pp., MacMillan, New York.

Horowitz, A. J. (2003), An evaluation of sediment rating curves for estimating suspended sediment concentrations for subsequent flux calculations, Hydrol. Processes, 17, 3387-3409.

Howard, A., and R. Dolan (1981), Geomorphology of the Colorado River in the Grand Canyon, J. Geol., 89, 269-298.

Johnson, W. J. (1994), Woodland expansion in the Platte River, Nebraska: Patterns and causes, Ecol. Monogr., 64(1), 45-84.

Johnson, W. J. (1998), Adjustment of riparian vegetation to river regulation in the Great Plains, USA, Wetlands, 18(4), 608-618.

Kellerhals, R., M. Church, and L. B. Davies (1979), Morphological effects of interbasin river diversions, Can. J. Civ. Eng., 6, 18-31.

Keown, M. P., E. A. Dardeau Jr., and E. M. Causey (1981), Characterization of the suspended-sediment regime and bed-material gradation of the Mississippi River basin, 874 pp., U.S. Army Corps of Eng. Waterw. Exp. Station, Vicksburg, Miss.

Lagasse, P. F. (1980), An assessment of the response of the Rio Grande to dam construction-Cochiti to Isleta reach, 133 pp., Albuquerque Eng. Dist., U.S. Army Corps of Eng., Albuquerque, N. M.

Lagasse, P. F. (1981), Geomorphic response of the Rio Grande to dam construction, in Environmental Geology and Hydrology in New Mexico, Spec. Publ. 10, edited by S. G. Wells and W. Lambert, pp. 27-46, N.M. Geol. Soc., Socorro, N. M.

Lane, E. W. (1955), The importance of fluvial morphology in hydraulic engineering, Am. Soc. Civ. Eng. Proc., 81, 1-17.

Leopold, L. B., and T. Maddock (1953), The hydraulic geometry of stream channels and some physiographic implications, U.S. Geol. Surv. Prof. Pap., 252.

Lyons, J. K., M. J. Pucherelli, and R. C. Clark (1992), Sediment transport and channel characteristics of a sand-bed portion of the Green River below Flaming Gorge Dam, Utah, Regul. Rivers Res. Manage., 7, 219-232.

Macek-Rowland, K. M. (2000), Suspended-sediment loads from major tributaries to the Missouri River between Garrison Dam and Lake Oahe, North Dakota, 1954-98, U.S. Geol. Water Resour. Invest. Rep., 00-4072, 24 pp.

Magilligan, F. J., and K. H. Nislow (2005), Changes in hydrologic regime by dams, Geomorphology, 71, 61-78.

Magilligan, F. J., K. H. Nislow, and B. E. Graber (2003), Scale-independent assessment of discharge reduction and riparian disconnectivity following flow regulation by dams, Geology, 31, 569-572.

Magirl, C. S., R. H. Webb, and P. G. Griffiths (2005), Changes in the water surface profile of the Colorado River in Grand Canyon, Arizona, between 1923 and 2000, Water Resour. Res., 41, W05021, doi:10.1029/ 2003 WR002519.

Marston, R. A., J. D. Mills, D. R. Wrazien, B. Bassett, and D. K. Splinter (2005), Effects of Jackson Lake Dam on the Snake River and its floodplain, Grand Teton National Park, Wyoming, USA, Geomorphology, 71, 79-98.

Meade, R. H., and R. S. Parker (1985), Sediment in rivers of the United States, in National Water Summary, 1984, U.S. Geol. Surv. Water Supply Pap., 1275, 49-60.

Nash, D. B. (1994), Effective sediment-transporting discharge from magnitude-frequency analysis, J. Geol., 102, 79-95.

Nelson, N. C. (2007), Hydrology and geomorphology of the Snake River in Grand Teton National Park, Wyoming, thesis, M.S., 79 p., Utah State Univ., Logan.

O’Connor, J. E., G. E. Grant, and T. L. Haluska (2003), Overview of geology, hydrology, geomorphology, and sediment budget of the Deschutes River basin, Oregon, in A Peculiar River: Geology, Geomor- phology, and Hydrology of the Deschutes River, Oregon, Water Sci. Appl., vol. 7, edited by J. E. O’Connor and G. E. Grant, pp. 7-29, AGU, Washington, D.C.

Petts, G. E. (1979), Complex response of river channel morphology subsequent to reservoir construction, Prog. Phys. Geogr., 3, 329-362.

Pitlick, J., and R. Cress (2000), Longitudinal trends in channel characteristics of the Colorado River and implications for food-web dynamics, Recovery Implementation Program Proj. 48-C, final report, 45 pp., Dep. of Geogr., Univ. of Colo., Boulder, Colo.

Pitlick, J., and R. Cress (2002), Downstream changes in the channel geometry of a large gravel bed river, Water Resour. Res., 38(10), 1216, doi:10.1029/2001WR000898.

Pitlick, J., M. VanSteeter, B. Barkett, R. Cress, and M. Franseen (1999), Geomorphology and hydrology of the Colorado and Gunnison rivers and implications for habitats used by endangered fishes, Recovery Implementation Program Proj. 44-B, final report, 57 pp., Dep. of Geogr., Univ. of Colo., Boulder, Colo.

Poff, L., J. D. Allan, M. B. Bain, J. R. Karr, K. L. Prestegaard, B. Richter, R. Sparks, and J. Stromberg (1997), The natural flow regime: A paradigm for river conservation and restoration, Bioscience, 54, 155-161.

Randle, T. J., J. K. Lyons, R. J. Christensen, and R. D. Stephen (2007), Colorado River ecosystem sediment augmentation appraisal engineering report, unpublished report, 78 pp., Denver Tech. Cent., U.S. Bur. of Reclam., Denver, Colo.

Richard, G. A. (2001), Quantification and prediction of lateral channel adjustment downstream from Cochiti Dam, Rio Grande, NM, Ph.D. dissertation, 229 pp., Colo. State Univ., Fort Collins.

Richter, B. D., J. V. Baumgartner, J. Powell, and D. P. Braun (1996), A method for assessing hydrologic alteration within ecosystems, Conserv. Biol., 10, 1163-1174.

Rubin, D. M., and D. J. Topping (2001), Quantifying the relative importance of flow regulation and grain-size regulation of suspended-sediment transport $(\alpha)$ and tracking changes in grain size on the bed $(\beta)$, Water Resour. Res., 37, 133-146.

Rubin, D. M., D. J. Topping, J. C. Schmidt, J. Hazel, M. Kaplinski, and T. S. Melis (2002), Recent sediment studies refute Glen Canyon Dam hypothesis, Eos Trans. $A G U, 83(25), 273$.

Schmidt, J. C., and D. M. Rubin (1995), Regulated streamflow, fine-grained deposits, and effective discharge in canyons with abundant debris fans, in Natural and Anthropogenic Influences in Fluvial Geomorphology, Geophys. Monogr. Ser., vol. 89, edited by J. E. Costa et al., pp. 177-195, AGU, Washington, D.C.

Schmidt, J. C., and J. B. Graf (1990), Aggradation and degradation of alluvial-sand deposits, 1965 to 1986 , Colorado River, Grand Canyon National Park, Arizona, U.S. Geol. Surv. Prof. Pap., 1493, 74 pp.

Schmidt, J. C., B. L. Everitt, and G. A. Richard (2003), Hydrology and geomorphology of the Rio Grande and implications for river restoration, in Aquatic Fauna of the Northern Chihuahuan Desert, Spec. Publ. 46, edited by G. P. Garrett and N. L. Allan, pp. 25-45, Mus. of Tex. Tech Univ., Lubbock, Tex.

Schmidt, J. C., D. J. Topping, P. E. Grams, and J. E. Hazel (2004), Systemwide changes in the distribution of fine sediment in the Colorado River corridor between Glen Canyon Dam and Bright Angel Creek, Arizona, final report, 107 pp., Grand Canyon Monit. and Res. Center, Flagstaff, Ariz.

Schumm, S. A. (1969), River metamorphosis, J. Hydraul. Div. Am. Soc. Civ. Eng., 1, 255-273.

Shields, F. D., Jr., A. Simon, and L. J. Steffen (2000), Reservoir effects on downstream river channel migration, Environ. Conserv., 27, 54-66.

Simon, A., F. D. Shields, R. Ettema, C. Alonso, M. Marshall-Garsjo, A. Curini, and L. Steffen (1999), Channel erosion on the Missouri River, Montana between Fort Peck Dam and the North Dakota border, 393 pp., Natl. Sediment. Lab., Agric. Res. Serv., U.S. Dep. of Agric., Oxford, Miss.

Stanley, J. W. (1951), Retrogression on the lower Colorado River after 1935, Am. Soc. Civ. Eng. Trans., 116, 943-957.

Stevens, J. C. (1938), The effect of silt-removal and flow-regulation on the regimen of Rio Grande and Colorado Rivers, Eos Trans. AGU, 19, 653659.

Stotz, N. G. (2000), Historic reconstruction of the ecology of the Rio Grande/Rio Bravo channel and floodplain in the Chihuahuan desert, 158 pp., Chihuahuan Desert Program, World Wildlife Fund, Las Cruces, N.M.

Thompson, K. R. (1984), Annual suspended-sediment loads in the Green River at Green River, Utah, 1930-82, U.S. Geol. Surv. Water Resour. Invest. Rep., 84-4169. 
Topping, D. J., D. M. Rubin, and L. E. Vierra Jr. (2000), Colorado River sediment transport: 1. Natural sediment supply limitation and the influence of Glen Canyon Dam, Water Resour. Res., 36, 515-542.

Topping, D. J., J. C. Schmidt, and L. E. Vierra Jr. (2003), Discharge of the Colorado River at Lees Ferry, Arizona, during the 1884 flood and between May 8, 1921, and September 30, 2000: Construction and analysis of a continuous record of instantaneous discharge, U.S. Geol. Surv. Prof. Pap., 1677.

U.S. Army Corps of Engineers (2000), Downstream channel and sediment trend study update, Sediment Memo. 16A, 22 pp., Garrison Proj., Missouri River Div., Omaha Dist., Hydrol. Eng. Branch, U.S. Army Corps of Eng., Omaha, Nebr.

U.S. Army Corps of Engineers (2004), Missouri River stage trends, $R C C$ Tech. Rep. A-04, 18 pp., Reservoir Control Cent., Northwest. Div.Missouri River Basin, Omaha, Nebr.

U.S. Bureau of Reclamation (1950), Report of river control work and investigations, lower Colorado River basin, calendar years 1948 and 1949, 125 pp., Boulder City, Nev.

U.S. Fish and Wildlife Service and Hoopa Valley Tribe (1998), Trinity River flow evaluation, draft final report, Arcata, Calif.

Van Steeter, M. M., and J. Pitlick (1998), Geomorphology and endangered fish habitats of the upper Colorado River: 1. Historic changes in streamflow, sediment load, and channel morphology, Water Resour. Res., 34, 287-302.

Wei, T. C. (1997), Downstream channel and sediment trends study, Fort Peck project, 55 pp., Omaha Dist., Hydrol. Eng. Branch, Eng. Div., U.S. Army Corps of Eng., Omaha, Nebr.
WEST Consultants (2002), Missouri River Gavins Point Dam degradation trends study, Contract DACW45-01-D0003, Task Order 0013, 26 pp., Omaha Dist., U.S. Army Corps of Eng., Omaha, Nebr.

White, M. A., J. C. Schmidt, and D. J. Topping (2005), Application of wavelet analysis for monitoring the hydrologic effects of dam operation: Glen Canyon Dam and the Colorado River at Lees Ferry, Arizona, River Res. Appl., 21, 551-565.

Wilcock, P. R., and S. T. Kenworthy (2002), A two-fraction model for the transport of sand/gravel mixtures, Water Resour. Res., 38(10), 1194, doi:10.1029/2001WR000684.

Williams, G. P. and M. G. Wolman (1984), Downstream effects of dams on alluvial rivers, U.S. Geol. Surv. Prof. Pap., 1286.

Woodson, R. C. (1961), Stabilization of the middle Rio Grande in New Mexico, J. Waterw. Harbors Div., 4, 1-15.

Woodson, R. C. and J. T. Martin (1963), The Rio Grande comprehensive plan in New Mexico and its effects on the river regime through the middle valley, in Proceedings of the Federal Interagency Sedimentation Conference, Misc. Publ. 970, pp. 357-365, U.S. Dep. of Agric., Washington, D.C.

J. C. Schmidt, Department of Watershed Sciences, Utah State University, 5210 Old Main Hill, Logan, UT 84322-5210, USA. (jack.schmidt@usu. edu)

P. R. Wilcock, Department of Geography and Environmental Engineering, Johns Hopkins University, 3400 Charles Street, Baltimore, MD 21218, USA. 